\title{
General Revenue Sharing and Public Sector Unions
}

\author{
Laura Feiveson* \\ Massachusetts Institute of Technology
}

December 18, 2012

\begin{abstract}
The United States federal government implemented a large general revenue sharing program from 1972 to 1986, in which it transferred nearly 300 billion (2009) dollars to over 35,000 state and local governments. I examine whether large city governments spent the funds that they received and how the strength of public sector bargaining affected whether the funds were spent on new employment or increased wages. I find that, on average, city governments spent the transfers completely, in contrast to the findings of some of the recent "flypaper" literature; and that cities in states with pro-union collective bargaining laws spent more than half of the transfers on increased wages while cities in states without such laws spent a greater fraction of the funds on new employment. These findings suggest that local institutions, in this case public sector unions, play an important role in determining the way intergovernmental grants translate into spending outcomes. They highlight the potential heterogeneity in the way such grants may be spent in different jurisdictions. Moreover, if raising the wages of existing workers has a different macroeconomic stimulative effect than hiring new workers, they may also suggest differences across places in the "multiplier" associated with federal transfers to state and local governments. I find suggestive, though weak, evidence that the output multiplier on spending on new employment is larger than the multiplier on increased government wages.
\end{abstract}

*I am very grateful to my advisors Jim Poterba and Michael Greenstone for their guidance and support. I also thank Olivier Blanchard, Francesco Giavazzi, Monica Martinez-Bravo, and seminar participants at MIT and SAIS for helpful comments and suggestions. 


\section{Introduction}

In 2012, the federal government transferred more than 600 billion dollars to state and local governments. Despite the pervasiveness of federal intergovernmental grants, there remains considerable debate surrounding their use at the local governmental level and their subsequent impact on economic activity and the provision of public goods. A relatively unexamined possibility is that heterogeneity at the local government level leads to substantial variation in the response of state and local governments to federal transfers. ${ }^{1}$ Despite the focus on labor markets in recent years, the interaction of public sector labor with local government budgeting has generally been neglected in the public finance literature. At the same time that policy debates surrounding the federal government's role in alleviating state and local government fiscal crises have rippled through Washington, protesters and politicians in Wisconsin, Indiana, and Ohio have brought public sector unions to the forefront of public consciousness. The theoretical underpinnings of research on public sector unions suggest that there may be a good reason to link the two debates.

In this paper, I seek to address this connection by examining how the strength of public sector labor unions affects the response of local governments to intergovernmental transfers. To approach this analysis, I revisit a general revenue sharing program put in place from 1972 to 1986 in which the federal government transferred a total of nearly 300 billion (2009) dollars to state and local governments. Although the stated goal of the law was to move the decisions about government spending "closer to the people", it simultaneously helped to alleviate liquidity crises at the state and local government level during a time period in which many local governments were facing budget deficits. Furthermore, the passage of the general revenue sharing legislation came at the end of a fifteen year period in which a rapid series of new state laws enabled or required local governments to collectively bargain with their employees. I use the diversity of the collective bargaining laws across states to examine how the laws affected city governments' use of the intergovernmental transfers and, in particular, I focus on whether they had influence over whether the transfers were spent on higher wages for existing employees or on new employment. I present an initial empirical estimate of the differential impacts on the private economy generated by these different types of government spending, providing motivation for future research.

The general revenue sharing program is a suitable program with which to study the effect of intergovernmental transfers on local government expenditure decisions for three main reasons. First, it significantly impacted the revenues of local governments. At its

\footnotetext{
${ }^{1}$ For instance, one well-studied example of a characteristic that has been shown to have significant effects at the state government level is the stringency of the balanced budget rules (Poterba (1994), Clemens and Miran (2011)).
} 
peak, general revenue sharing made up to 20 percent of total revenues of the large city governments studied in this paper.

Second, there was substantial and plausibly exogenous variation in the amounts that city governments received. Although the general revenue sharing formula depended on three factors that would be expected to have a separate effect on government expenditure decisions (per capita income, tax-to-income ratio, and population), a "geographic tiering" element to the formula led to variation in the general revenue sharing receipts of city governments that were housed in different counties and states, but were otherwise very similar. Furthermore, the three factors entered the allocation formula in highly nonlinear ways, making it possible to control for them directly. Since the magnitude of transfers to a local government is often correlated to its economic conditions, it can be difficult to disentangle the effects of the transfers from the effects of the economy. Because of the eccentricities in the formula, the general revenue sharing program provides variation that is plausibly immune to this concern.

Finally, the general revenue sharing program led to transfers to over 35,000 state and local governments including all state, county, city, town and township general-purpose governments. It was one of the most comprehensive general purpose transfer programs in the history of the United States and provides a test case for possible future general revenue sharing designs.

Although private sector unions were granted full legislative protection in the first half of the twentieth century, public sector unions did not achieve significant legislative gains until the late-1950s and 1960s. ${ }^{2}$ However, starting with Massachusetts in 1958 and Wisconsin in 1959, a series of state laws were passed in rapid succession. By the time that the State and Local Fiscal Assistance Act instituted the first wave of general revenue sharing in 1972, 30 states had passed laws enabling or requiring collecting bargaining by local governments within their state. Figure 1 plots the number of workers and the percent of workers covered by private and public sector unions from 1977 to 2010. The percent of public sector workers covered by unions has remained roughly constant at 40 percent for the period shown. The absolute number of public sector workers covered by unions actually exceeded the number of private sector workers for the first time in 2009. ${ }^{3}$ Since public sector collective bargaining was pervasive by the time that general revenue sharing was put in place, it is possible to study how the strength of collective bargaining affected the local governments' use of the

\footnotetext{
${ }^{2}$ The landmark laws supporting the right to unionize, strike, and collectively bargain in the private sector, i.e. the National Labor Relations act in 1935 and the Taft-Hartley Act in 1947, specifically left out public sector unions.

${ }^{3}$ These statistics are from the Survey on Labor-Management Relations in State and Local Governments (U.S. Bureau of the Census, Multiple Years) and www.unionstats.com (Hirsch and Macpherson, 2003).
} 
transfers.

The empirical analysis of this paper is organized into three main parts. First, the general revenue sharing program provides an opportunity to revisit the much-studied research question of whether governments used the transfers to increase expenditures or to reduce taxes. An influential paper by Bradford and Oates (1971) theorized that lump-sum intergovernmental transfers should have the same effect on government expenditures as an equivalent increase in personal income of the voting citizens. An extensive empirical literature has emerged since this paper, which has found that intergovernmental transfers, at times, lead to a much higher increase in government expenditures that would plausibly result from an equivalent rise in personal income. This phenomenon has been dubbed the "flypaper effect" because the transfer funds appear to stick where they hit. ${ }^{4}$ The flypaper effect remains an important policy issue; as the federal government considers transferring funds to local governments, the question of whether they will spend the funds is crucial to the policy evaluation. I find that the large cities I study in this paper increased expenditures by roughly one dollar for every dollar received in intergovernmental transfers. ${ }^{5}$

Second, I examine how the strength of public sector collective bargaining laws affects the expenditure decisions of the recipient governments. Theories of public sector unions conjecture that union leaders seek to maximize an objective function in which wages and employment are positive inputs. These theories suggest that bargaining in cities in states with pro-union bargaining laws may lead to different uses of transfers than in cities in states with no such laws. I find that the cities with strong collective bargaining laws convert more of the transfers into increased wages than those with no bargaining laws, and, furthermore, that those with no bargaining laws instead spent a significant amount of funds on new or retained employment.

Lastly, I consider one possible implication of these findings. The American Recovery and Reinvestment Act of 2009 (ARRA) included more than 200 billion dollars of transfers to state

\footnotetext{
${ }^{4}$ As summarized by Gramlich (1977) and Hines and Thaler (1995), the empirical literature in the latter half of the century had shown the existence of a strong flypaper effect. Explanations of the flypaper effect range from discussions of a mis-specified model of citizen behavior (see Filimon, Romer and Rosenthal (1982) or Hines and Thaler (1995)) to a repeated game element in the grant process (Chernick (1979)). Inman (2008) provides a comprehensive discussion of other possible explanations. More recent empirical studies have shown more ambiguous results; the flypaper effect seems to at least crucially depend on factors such as the type of democracy (Lutz (2006)) and the strength of collective interest groups (Singhal (2008)). Furthermore, Knight (2002) argued that the possible endogeneity of grant assignment due to differential preferences for government spending may have led to econometric issues in previous studies, and finds a negligible flypaper effect in transportation grants to state governments when appropriately accounting for legislative bargaining power.

${ }^{5}$ Because the general revenue sharing program did include some minor price effects, they were not pure lump sum transfers and thus do not directly address the traditional flypaper effect. Details of the general revenue sharing program and how they relate to the flypaper effect will be discussed in Sections 2 and 6.2.
} 
and local governments. The magnitude of this component of the stimulus component has led to a renewed interest in the estimation of the government spending multipliers associated with intergovernmental transfers. ${ }^{6}$ My results suggest that public sector unions may be a factor in the determination of the size of these multipliers. Starting with Wynne (1992), a distinction in the theoretical and empirical literature has been made between the stimulative effects on the private economy of government consumption of private goods and government compensation of employees. ${ }^{7}$ A similar distinction can be made between government spending on increased government wages and increased government employment, due to differential marginal propensities to consume between the two types of recipient employees. Because the strength of collective bargaining laws determines the type of government spending produced, I use this institutional friction to explore the hypothesis that the multipliers on spending on increased wages and on spending on new employment would be different. I find suggestive, though weak, evidence that the multiplier on increased government employment is larger than the multiplier on increased government wages for existing employees. These results are presented as motivation for future research.

The paper is organized as follows: Section II discusses the framework for the analysis. Section III reviews the program details of the general revenue sharing transfers, Section IV introduces the empirical strategy, Section V explains the data that are used, and Section VI discusses the main results. Section VII introduces the macroeconomic hypothesis and empirical analysis. Finally, Section VIII concludes.

\section{Framework}

In this section, I consider how the public sector unions might seek to influence the use of intergovernmental transfers at the local government level. The standard consensus is that the public sector union has a utility function over wages and employment, increasing in both (Dunlop (1944), Farber (1986)). ${ }^{8}$ The intuition of why wages are in the utility function is clear; we generally think that an increase in income, given the same amount of work, yields

\footnotetext{
${ }^{6}$ A number of studies have directly estimated the multipliers associated with this component of the ARRA: Chodorow-Reich et al (2012), Cogan and Taylor (2011), Conley and Dupor (2012).

${ }^{7}$ See Finn (1998), Pappa (2009), and Ramey (2011).

${ }^{8}$ This is a simplification of a very large literature. Starting with Ross (1948), there has been debate over the value of assigning a well-defined utility function to the labor representation. In particular, political motivations of union leadership and heterogeneous membership make the objectives difficult to summarize. Ashenfelter and Johnson (1969) propose an alternative bargaining model in which there are three parties: the firm management, the union leadership, and the union "rank and file". In this spirit, many recent papers stress the political motivation of the union leadership in their models of union behavior.
} 
an increase in utility. ${ }^{9}$ However, the idea that the union leadership would also value higher levels of employment is less obvious. ${ }^{10}$ The theories that advocate for having employment in the utility function mostly rely on the idea that higher levels of employment increase the negotiating power of the public sector union members. In addition, some economists have argued that public sector unions put greater weight on employment than private sector unions because numbers boost the ability of the union to sway elections (Courant, Gramlich, and Rubinfeld (1979), Freeman (1986)). On the other hand, advocates of the "insider-outsider" theory conjecture that the current members care only about their own wages and job security without any direct desire to increase employment (Blanchard and Summers 1986). ${ }^{11}$ Finally, it is worth pointing out that the objective functions of public sector unions may include more than just wages, employment, or personal benefits; in particular, because public sector employees have influence over the provision of public goods, they may also include the welfare of citizens in their utility function. For example, one reason that public sector unions may lobby for more public funds is that they have an in-depth understanding of how to supply services in the most effective way (Zax and Ichniowski 1988).

Motivated by these considerations about the union's objectives, the intergovernmental grant utilization decision that I particularly focus on is whether the transfer funds are spent on wages, $w$, or new employment, $E$. In my stylized world, all local government expenditures are on labor such that the relationship between $E$ and $w$ is constrained by the allotted local government budget, $B$, satisfying the budget constraint, $B=w E$. When a grant is received by a local government, the flypaper effect leads to an outward shift in this labor demand curve, such that $B^{\prime}=B+\mu_{f} T=w E$, where $\mu_{f}$ is the percent of the transfers that is retained by the government rather than returned to the taxpayers in the form of reduced taxes. ${ }^{12}$ On the labor supply side, I assume that the union can choose the point on the labor demand curve that maximizes their objective function. The left panel of Figure 2 shows one possible

\footnotetext{
${ }^{9}$ Empirical evidence has shown that there is a significant union-nonunion public sector wage gap. See Lewis (1990), Zax and Ichniowski (1988), Hoxby (1996), and Frandsen (2011).

${ }^{10}$ The empirical evidence is also mixed. While Zax and Ichniowski (1988) found a significant effect of unionization on employment, others have found that omitted variables may have biased naive regressions of employment on unionization. Trejo (1991) argued that economies of scale led to more union formation in larger municipalities, leading to a natural correlation between unionization and employment that could be deceptively interpreted causally. Valletta (1993) argued that municipalities with high levels of volunteerism or privatization tend to have fewer unions and smaller governments.

${ }^{11}$ By limiting the discussion of the objective function to only employment or wages, I am skimming over other variables that have been included in the utility functions of unions. For instance, in the utility function posited by Blanchard, Summers (1986), the union members valued wages and the probability of retaining their job in the next period. It is also worth mentioning that their model surrounds the private sector rather than the public sector.

${ }^{12}$ It is important to note that $\mu_{f}$ may itself be effected by the extent of unionization, a possibility that I explore in the empirical analysis.
} 
outcome when the supply curve is shifted outward in which both employment and wages increase. ${ }^{13}$ In the other extreme, the governments that are not subject to strong unions instead face competitive wages for government workers. Thus, the labor demand curve is flat, and any expansion in the budget has no effect on wages and is used directly to increase government employment as demonstrated in the right side of Figure 2.

Obviously, these are extreme cases and I write them only to illustrate how public sector unions may lead to a different utilization of transfers than what would occur in their absence. The mechanism I describe above implicitly assumes that the public sector union is aware of and able to bargain over the change in the budget to reach their optimal point on the budget curve. This assumption might break down for other shifts to the budget such as business cycle related changes to tax revenue. Since intergovernmental transfers are announced and have a very specific timing attached to them, their arrival is a concrete item over which to bargain. As the events of 2011 and 2012 in many of the Midwestern states have proved, public sector unions are strong forces at the bargaining table, and it is likely that they will influence the use of transfers in the ways I stylized above even if they are unable to influence the response to other more intangible income shocks. ${ }^{14}$

\section{General Revenue Sharing}

The policy debates surrounding the growing roles of local governments in the late 1960s and early 1970s ultimately led to the passage of the State and Local Fiscal Assistance Act in October of 1972. This act put in place the largest general revenue sharing scheme in the history of the United States. With this policy, the federal government initially committed to transferring over 30 billion dollars to more than 35,000 general purpose governmentsstate, county, city, town, and township governments-over a period of 4 years. In 1976, the act was extended for another period of 4 years for state and local governments, and then extended for only local governments from 1980 to 1983 and again from 1983 to 1986 when it finally expired. By the end of the act, over 83 billion dollars (almost 300 billion in 2009 dollars) had been transferred to state and local governments. The motivations for

\footnotetext{
${ }^{13}$ Certainly utility functions exist such that the unions would choose to decrease either wages or employment when the budget is increased, if the cross partials are negative. However, I think it is completely reasonable to assume that, at the very least, political economy constraints would ensure that wages and employment both weakly increase when there is an expanded budget. The purposes of this graph are to be illustrative and I leave it to the empirics to be exact about what would actually happen.

${ }^{14}$ Relatedly, Allen (1998) address the question of how public sector unions affect employment in the presence of negative revenue shocks. Because of the reasons just outlined above, this question does not directly relate to the questions that I address in this paper. He finds that, contrasting with the dymanics in the private sector, union workers in the public sector face lower rates of unemployment than nonunion workers when faced with revenue losses.
} 
the act were both philosophical and practical; the official goal was to have decisions about government spending "closer to the people", while the act simultaneously served the purpose of providing support to local governments at a time in which many budgets were strained. Although some evidence implies that the Nixon administration had the intention of using the general revenue sharing funds to replace various federal categorical grant programs to local governments, in practice, it acted as a supplement to the programs that already existed. ${ }^{15}$ The most binding requirement surrounding the use of the funds was that they were not to be used for operational education expenses; no general revenue sharing funds were transferred to school districts. Otherwise, the governments had almost complete freedom to use the funds as they desired. ${ }^{16}$ The governments did have to fill out a "statement of use" in which they described how they used the funds. ${ }^{17} \quad$ Furthermore, after the first extension of the funds, the local governments were required to hold public hearings in which the potential uses of the funds were discussed.

Table 1 shows the size of the program throughout the 14 years of its existence. At the peak of the program's impact, in 1974, general revenue sharing (GRS) made up about 15 percent of total federal intergovernmental transfers to state and local governments, and composed almost 3 percent of state government budgets and over 3.5 percent of local government budgets. As Table 1 shows clearly, the size of the program in real dollars decreased substantially over its tenure due to relatively high inflation in the 1970 s and the 1980s combined with stagnant nominal amounts. By 1984, the program only amounted to 0.12 percent of GDP and less than 2 percent of local government budgets. Despite the ramp-down, the general revenue sharing program had a substantial effect on the revenues of the 837 cities in my sample. Figure 3 plots both the total federal intergovernmental funds as well as the total general revenue sharing funds received by the city governments. The figure demonstrates

\footnotetext{
${ }^{15}$ In fact, the Nixon administration promised that the general revenue sharing program would be an "addon" to existing programs in order to get the support for the passage of the act (Dommel, 1974). However, after the act was passed and Nixon was re-elected in 1972, the administration began to push for the elimination of many block grant programs, claiming that the general revenue sharing funds would make up for the reduced transfers. The Watergate scandal ultimately interfered with the implementation of this policy push, and the grant programs remained largely unscathed, reinforcing the "add-on" nature of the general revenue sharing program (Markusen et al, 1981).

${ }^{16}$ Specifically, the "priority" categories on which the funds could be spent were: all "ordinary and necessary" capital expenditures, and "ordinary and necessary" maintenance and operating expenses for public safety, environmental protection (including sewerage and sanitation), public transportation, health, recreation, libraries, social services for the poor or aged, and financial administration (Joint Committee on Internal Revenue Taxation, 1973). In practice, the only major binding requirement was that the funds were not to be used for education operating expenses.

${ }^{17}$ The specific requirements were the the funds had to be appropriated within 24 months of the entitlement period. Local governments had to fill out planned use and actual use reports and make them available to the public. The planned use reports were to be filled out within each entitlement period while the actual use reports were to be filled out within 60 days of June 30th of each year.
} 
that the movements in total federal intergovernmental transfers appeared to reflect the jump in general revenue sharing funds in the early-1970s as well as the ramp-down in the earlyto mid- 1980s.

\subsection{GRS Allocations}

As with any large federal program, there was a significant amount of negotiation involved with the allocation of the general revenue sharing funds. The compromise finally reached between the members of the Congress led to rich variation in the amount that local governments received. One of the key features of the allocation formula is that the funds were allocated with a method of "geographic tiering"; first the funds were allocated to state areas using a federally-mandated formula; then, after removing a portion for state governments, the funds were apportioned to county areas using a federally-mandated formula; then, again after removing funds for county governments and Native American tribes they were divided amongst city, town, and township general purpose governments using the same federallymandated formula. The diagram below demonstrates this allocation process.

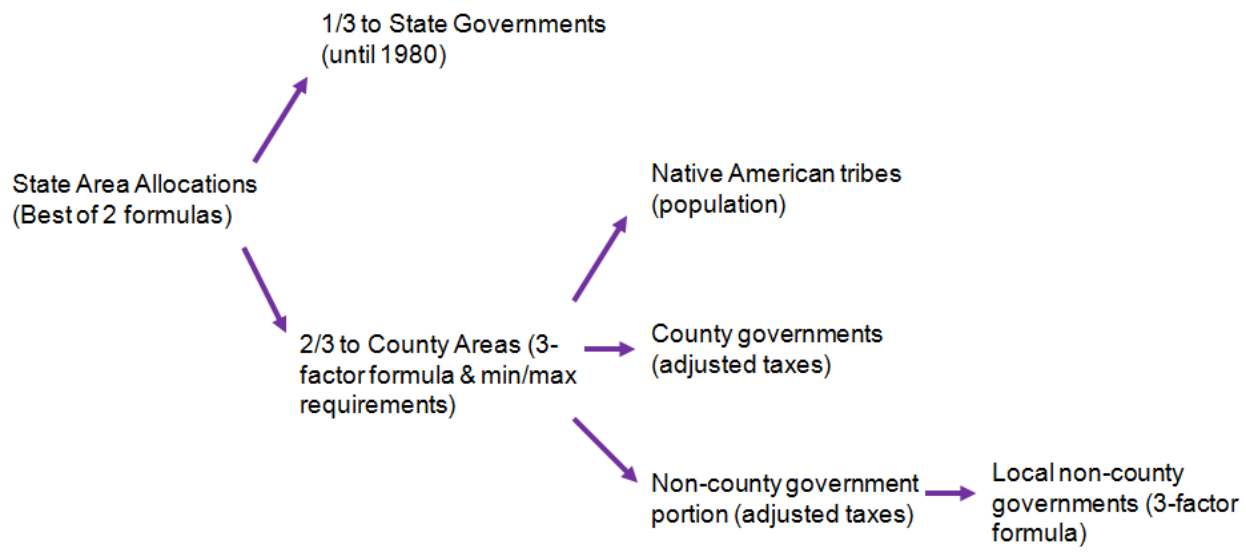

This "geographic tiering" led to a wide dispersion of general revenue sharing funds across cities that were similar, but that were housed in counties and states with different characteristics. The formulas are described in detail in the next three subsections.

Allocations to States The funds were first allocated to the state areas using one of two formulas. The first, called the three-factor formula-or the Senate formula-allocated money to states in proportion to a factor, $F_{i}$ :

$$
F_{i}=\operatorname{Pop}_{i} *\left(\frac{\operatorname{Tax}_{i}}{\text { PersonalIncome }_{i}}\right) *\left(\frac{\text { PerCapitaIncome }_{U S}}{\text { PerCapitaIncome }_{i}}\right)
$$


The first term of this factor was geared towards equalizing the per capita funds transferred to states. The second component was to address the concern that states may lower taxes in response to the increased federal funds; to try to reduce the incentives to do this, high taxation rates were rewarded. Finally, the third term transferred more funds to states that had lower per capita income. Under this allocation formula, each state $i$ was awarded, $S_{i}^{1}$ :

$$
S_{i}^{1}=G *\left(\frac{F_{i}}{\sum_{\text {States }} F_{k}}\right)
$$

where $G$ was the total amount of general revenue sharing funds available for distribution.

In the second, five-factor (House) formula, the allocation was divided into five parts which were each distributed using a different formula as shown in the table below:

\begin{tabular}{|c|c|}
\hline Fraction of Funds & Factor used for Allocation \\
\hline 0.25 & Pop $_{i}$ \\
\hline 0.25 & UrbanPop $_{i}$ \\
\hline 0.25 & Pop $_{i} *\left(\frac{\text { PerCapitaIncome }_{U S}}{\text { PerCapitaIncome }_{i}}\right)$ \\
\hline 0.125 & IncomeTax $_{i}$ \\
\hline 0.125 & Tax $_{i} *\left(\frac{\text { Tax }_{i}}{\text { PersonalIncome }_{i}}\right)$ \\
\hline
\end{tabular}

Under this formula, the total GRS allocation was divided into parts and then distributed according to the factors discussed in the table above. Each state was awarded $S_{i}^{2}$ :

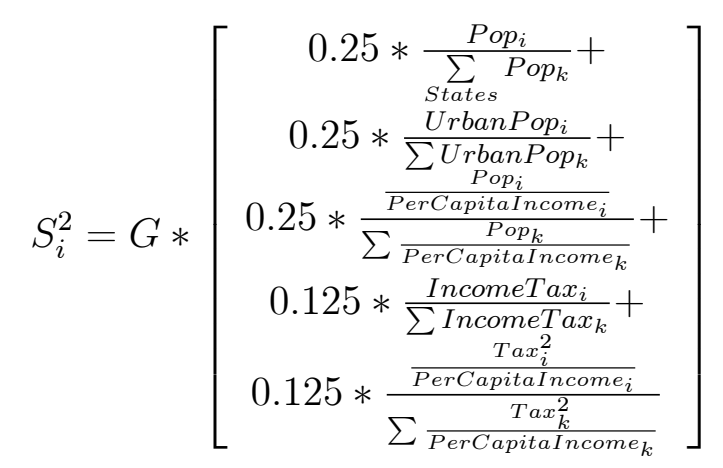

The final allocation was reached by first calculating the distribution of funds, $S_{i}^{1}$ and $S_{i}^{2}$, for all of the states under each of the three-factor and the five-factor formulas, and then taking the larger of the two amounts for each state. These final amounts were then proportionately adjusted so that the total amount summed to the total GRS funds available. The final allocation for each state area was then:

$$
S_{i}^{F}=G * \frac{\max \left(S_{i}^{1}, S_{i}^{2}\right)}{\sum \max \left(S_{k}^{1}, S_{k}^{2}\right)}
$$


Ultimately, 31 states received their revenue-sharing allotment based on the three-factor formula and 19 states and DC received their revenue-sharing allotment based on the five-factor formula. Figure 4 shows the distribution of the 1977 state area allocations.

Allocations to local governments Of the amount allocated to states, one-third was designated for the state government and two-thirds was designated for the local governments within the states. The path for the funds to reach local governments went first through county area allocations. The funds were allocated to counties using the three-factor formula from above so that each county, $c$, in a state, $s$, received funds proportional to:

$$
F_{c s}=\text { Pop }_{c} *\left(\frac{\text { NonSchoolTax }_{c}}{\text { PersonalIncome }_{c}}\right) *\left(\frac{\text { PerCapitaIncome }_{s}}{\text { PerCapitaIncome }_{c}}\right)
$$

where NonSchoolTax $_{c}$ are the total taxes raised in local governments in the county less the taxes dedicated for educational expenses. ${ }^{18}$ After a population-based amount was removed for Native American tribes within the county, the county area allocation was then divided into three parts designating funds for the county government, the city and town governments, and the township governments based on their relative non-school tax collection. Finally, the city and town governments and the township governments within a county each split their group's total allocation amongst the individual governments according to proportions once again determined by the three-factor formula. The final allocation formula to a city, $i$, in county, $c$, and state, $s$, was:

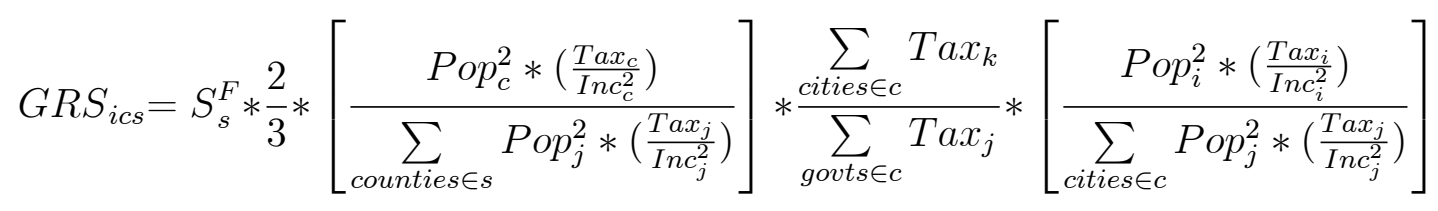

where $S_{s}^{F}$ is the state-area allocation. ${ }^{19}$

Minimum and Maximum Requirements Minimum and maximum requirements further distorted the funds received by local governments. There were three main limits. The first requirement was that no local government was allowed to receive a grant that constituted more than 50 percent of its total nonschool taxes and intergovernmental transfers. When the amount allocated to a city or town exceeded this limit, the excess amount was

\footnotetext{
${ }^{18}$ The details of the legislation actually gave states some freedom to change the formula with which the state area allocations were divided amongst local governments. However, none of the state governments chose to take up this option and the federal formula was used in all cases.

${ }^{19}$ The allocation amount would be slightly less than implied by the formula in Equation (6) for cities in counties that included a Native American population.
} 
reallocated to the corresponding county government. When the amount allocated to the county government exceeded this amount, the funds went back to the state government. Because of this restriction, more than 10 state governments received more than one-third of their state's allocation, with West Virginia, Kentucky, and Delaware receiving substantially more than the one-third initially allocated (45\%, 41\%, and 40\% respectively).

The second limit was that no county area or local government was permitted to receive more than 145 percent of the state per capita amount, and the third limit was that no county area or local government was permitted to receive less than $20 \%$ of the state per capita amount. At the county area level, those funds that were in excess of the 145 percent limit were distributed to the non-binding county areas proportionate to the three-factor formula. Similarly, funds were reduced proportionately in non-binding county areas to meet the 20 percent limit for those areas that needed extra funds. Similar adjustments occurred for those local governments that were constrained at the 20 percent or the 145 percent limits.

To be clear, I will map out the steps in which city governments were received funds from their county-wide allocations. Suppose that a county area received $G R S_{0 c}$ through the allocation process. A city government, $i$, within the county would initially receive ${ }^{20}$ :

$$
\begin{aligned}
G R S_{0 i}= & \left(\frac{\operatorname{Pop}_{i} *\left(\frac{\text { NonSchoolTax }_{i}}{\text { PersonalIncome1969 }_{i}}\right) *\left(\frac{\text { PerCapitaIncome }_{i}}{\text { PerCapitaIncome }_{c}}\right)}{\sum_{\text {cities }} \operatorname{Pop}_{j} *\left(\frac{\text { NonSchoolTax }_{j}}{{\text { PersonalIncome } 1969_{j}}_{j}}\right) *\left(\frac{\text { PerCapitaIncome }_{j}}{\text { PerCapitaIncome }_{c}}\right)}\right) \\
& * G R S_{c} *\left(\frac{\sum_{\text {Cities }} \text { NonSchoolTax }_{k}}{\sum_{\text {GovernmentsInCounty }} \text { NonSchoolTax }_{j}}\right)
\end{aligned}
$$

The first additional requirement was that the city government did not receive more than fifty percent of its total nonschool taxes and intergovernmental transfers. Thus, in the second step of the allocation, the city government received $G R S_{1 i}$ :

$$
G R S_{1 i}=\min \left(G R S_{0 i}, 0.5 *\left(\text { NonSchoolTax }_{i}+I G R_{i}\right)\right)
$$

Any excess amounts generated in this step, $G R S_{0 i}-G R S_{1 i}$, were assigned to the county governments within the county. The second and third limits were then applied such that:

$$
G R S_{2_{i}}=\min \left(\max \left(G R S_{1 i}, 0.2 *\left(\frac{G R S_{s}}{P o p_{s}}\right)\right), 1.45 *\left(\frac{G R S_{s}}{P o p_{s}}\right)\right)
$$

\footnotetext{
${ }^{20}$ If there were Native American Tribes in the county, a portion of $G R S_{c}$ would be removed before the allocation in Equation (6).
} 
Any excess amounts generated in this step, $G R S_{1 i}-G R S_{2 i}$, were added to the initial countywide allocation, $G R S_{c}$, and any shortage of funds generated, $G R S_{2 i}-G R S_{1 i}$ were subtracted from $G R S_{c}$. At this point, the steps represented in Equations (7) - (9) would be repeated again until all binding requirements were met. ${ }^{21}$ Note that, due to the iteration of these steps, the maximum and minimum requirements ended up affecting the allocations of governments that were not at the limits of the requirements. In the first year of the GRS program, 6.6 percent of the GRS funds were redistributed through limits and only 74 out of the 38,000 recipients had allocations which were unaffected by the limit requirements.

\subsection{Variation in GRS receipts}

Any examination of the GRS aggregates will mask the significant variation in the per capita funds received by local governments due to the geographic tiering and other nuances of the allocation process. The variation is especially large at the city level, which is the unit of observation in this paper. To give a sense of the variation, in Figure 5, I plot a histogram of the de-meaned per capita general revenue sharing transfers in 1977. Although the variation in Figures 5 is useful to observe, the variation that I will use in future regressions is the residual left once I control for smooth functions of all of the variables that appear in the allocation formulas in Equations (1) - (9). Figure 6 shows the residuals from a regression of per capita general revenue sharing receipts on cubic polynomials of all of the allocation variables in 1977..$^{22}$ Due to the geographic tiering and the non-linearity of the allocation formulas, this figure shows that substantial cross-sectional variation in the general revenue sharing funds remain even after controlling for flexible functions of the allocation variables.

\section{Empirical Strategy}

I estimate how cities respond to intergovernmental transfers, and how the strength of public sector collective bargaining affects that response. The main estimation equation is:

$$
E_{i t}=\beta_{0}+\beta_{1} I G R_{i t}+\beta_{2} I G R_{i t} * U_{i t}+\beta_{3} U_{i t}+\mathbf{X}_{i t} \boldsymbol{\eta}+\lambda_{i}+\omega_{t}+\varepsilon_{i t}
$$

where $E_{i t}$ is a per capita government finance component in government $i$ and year $t, I G R_{i t}$ are the per capita intergovernmental transfers, $U_{i t}$ is an indicator for the strength of collective bargaining laws, $\lambda_{i}$ are city fixed effects, and $\omega_{t}$ are time fixed effects. $X_{i t}$ is a set of control

\footnotetext{
${ }^{21}$ If, at any step, the amount allocated to the county government exceeded 50 percent of the sum of its nonschool taxes and intergovernmental transfers, the excess would be allocated to the state government.

${ }^{22}$ The detailed list of controls will be discussed in Section 5.7.
} 
variables including cubic polynomials of population, lagged per capita tax revenue, lagged tax effort, lagged own-source revenue, lagged per capita county income, lagged state-level total taxes, lagged state per capita income, and lagged state government individual income taxes. Although I show the results for a number of finance components, the outcome variables that I particularly focus on are total real expenditures, public employee real wages, and the number of public employees. The effect of the transfers on total expenditures will demonstrate whether governments spend the funds transferred to them (i.e. the expenditure effect), while the latter two outcome variables will speak to the quality of the public spending. Later in the paper, I discuss how the quality of public spending might impact the stimulative effectiveness of transfers to city governments, particularly during recessions.

An issue with the estimation of Equation (10) is that the federal and state governments target some of their funds to cities or areas that are in particular need. This could bias $\beta_{1}$ and $\beta_{2}$ either downward or upward if there is a systematic difference in how city governments "in need" and other cities respond to the transfers. For example, if funds are transferred to cities with high unemployment, reversion to the mean may mistakenly attribute an improvement in economic conditions (and thus an increase in government expenditures) to the transfers received. On the other hand, if funds are transferred to cities that are beginning to experience budgetary problems, the continuation of the negative trend (leading to a contraction in government expenditure) may be wrongly attributed to the transfers, biasing the $\beta$ coefficient downwards.

\subsection{A 2SLS Approach}

To address the problem of potential bias, I use the general revenue sharing transfers as an instrument for total intergovernmental transfers. In particular, I have two instruments, $G R S_{i t}$, per capita general revenue sharing receipts, and $G R S_{i t} * U_{i t}$, per capita general revenue sharing receipts interacted with the indicator for bargaining strength, for the two endogenous variables, $I G R_{i t}$ and $I G R_{i t} * U_{i t}$. Because I control for the cubic polynomials of all of the $G R S$-correlated variables, my instruments are essentially the $G R S_{i t}$ and the $G R S_{i t} * U_{i t}$ after conditioning for these variables. I estimate using 2SLS estimation, in which the second stage is represented by Equation (10), and the two first-stage regressions are:

$$
I G R_{i t}=\varphi_{0}^{A}+\varphi_{1}^{A} G R S_{i t}+\varphi_{2}^{A} G R S_{i t} * U_{i t}+\varphi_{3}^{A} U_{i t}+\mathbf{X}_{i t} \boldsymbol{\alpha}^{A}+\sigma_{i}^{A}+\mu_{t}^{A}+\nu_{i t}^{A}
$$




$$
I G R_{i t} * U_{i t}=\varphi_{0}^{B}+\varphi_{1}^{B} G R S_{i t}+\varphi_{2}^{B} G R S_{i t} * U_{i t}+\varphi_{3}^{B} U_{i t}+\mathbf{X}_{i t} \boldsymbol{\alpha}^{B}+\sigma_{i}^{B}+\mu_{t}^{B}+\nu_{i t}^{B}
$$

The exclusion restriction of the IV estimation is that $G R S_{i t}$ and $G R S_{i t} * U_{i t}$ are independent of the error term in Equation (10). As described above, the nonlinearities in the general revenue sharing formula ensured that similar cities received different amounts of funds. However, the three-factor and five-factor formulas imply that the GRS transfers were correlated to per capita income, non-school "tax effort", and population of the city governments, as well as the higher-level variables used for the allocation to their encompassing counties and states. Assuming that the expenditures are independent of all of these variables would be implausible; in particular, the city-level tax effort, taxes and population as well as the county-level per capita income seem likely to have an effect on city government expenditure decisions in perhaps a nonlinear way. ${ }^{23}$ To satisfy the exclusion restriction given my assumptions, I include a flexible cubic polynomial of the lags of each of the variables that are used in the general revenue sharing calculation. ${ }^{24}$ Details on the sources of the controls are described in the next section.

Given the independence of $G R S_{i t}$, I argue that $G R S_{i t} * U_{i t}$ is also independent of the error term in Equation (10). Since most of the law changes to $U_{i t}$ occurred before the estimation time period, the city fixed effects will largely pick up the city characteristics that may have been correlated to $U_{i t}$. However, there is a concern that the controls included to ensure the independence of the $G R S_{i t}$, i.e. the city-level tax effort, taxes, and population, and county income, may affect "no-bargaining" cities in a different way than "bargaining" cities. To account for this possibility, I also interact each control with the bargaining indicator, $U_{i t}$, in my preferred specification.

Finally, for those cities that were parts of states that instituted bargaining laws within the sample studied, there is the concern that factors present within the cities (and reflected in city government finance decisions) affected the timing of the passage of the laws. If this were the case, than it is possible that $U_{i t}$ is correlated with $\varepsilon_{i t}$ in Equation (10). As is shown in Figure 8, 8 states passed laws during the period studied, changing their value of $U_{i t}$. Extensive research on the collective bargaining laws carried out in the late 1980s found

\footnotetext{
${ }^{23}$ Because the city-level per capita personal income is only released every 10 years, the (annual) countylevel per capita income is the variable in the GRS formula that best proxies fluctuations in local-area personal income.

${ }^{24}$ The general revenue sharing allocations were updated quarterly with the most current data available. In practice, this meant that the data used in the GRS formula were lagged at least 2 to 4 quarters. To best approximate this lag with annual variables, I include all controls with a one-year lag. Furthermore, I do not include county-level controls or the state-level urban population, since these variables were not updated on an annual basis.
} 
that, given that the change was ultimately going to occur, the timing of the law passages were largely exogenous, having more to do with the superficial political environment of the state legislature than the political or public will towards collective bargaining. Ohio is a good example of this; although Ohio had some of the strongest private sector unions in the country, they were one of the last states to pass a public sector bargaining law in 1985. Although the will of labor and the public had been behind the law for many years, haggling over the details of the law lead to a long delay. Saltzman (1988) documents this delay, and also argues convincingly that the passage of the law in Ohio had a significant effect on the strength of its public sector unions. Freeman and Valletta (1988) also provide evidence that the state laws were a major factor in determining whether public sector employees were covered by collective bargaining contracts. Given this research surrounding the timing of the laws, it may be reasonable to assume that the city fixed effects will pick up any political or public will toward collective bargaining so that the timing of the law change and $U_{i t}$, and $G R S_{i t} * U_{i t}$, remain independent of the error term.

\subsection{Further Assumptions}

To ensure the validity of the empirical strategy outlined above, I must make two more assumptions. First, I assume that the dependent varible in Equation (10) depends only on contemporaneous general revenue sharing funds, and not on lagged or future general revenue sharing funds. Since $G R S_{i t}$ can affect future values of itself through macroeconomic effects on $I_{i t}$ or any of the other correlates, changes to $G R S_{i t}$ may be correlated over time. By only including the contemporaneous change, I introduce an omitted variables problem if the true relationship actually consisted of the dependent variables depending on future or past values of $G R S_{i t}$. I test this by including past and future values of $G R S_{i t}$ in the estimation equation. I find that the results are little changed, although the standard errors increase.

Second, I assume that the coefficients on $G R S$-correlated cubic controls are constant over time. This would not be true, for example, if different governors or mayors weigh personal income differently when determining budgeting policies. If the coefficients are not constant over time, the cubic controls as described in Section 4.1 would not appropriately account for that portion of the general revenue sharing variation that was due to fluctuations in its correlates. To deal with this possibility, in a robustness check, I interacted all of the controls with year dummies and include them in the main specification. I find that the direction of the main results are little changed. In my preferred specification, however, I do not include the control-time interactions.

Further robustness measures are reported in Section 6. 


\section{Data}

In this section, I describe the sample used for the analysis, the data sources, and the summary statistics. In the appendix, I include an additional explanation of the adjustment I make to account for the variation in the fiscal years covered by the Annual Survey of Governments.

\subsection{The Sample}

State and local governments are often under-emphasized in analyses of the government spending in the United States. In the 2000s, federal nondefense consumption and investment made up only about 2 percent of GDP in comparison to that of state governments which made up 4 percent of GDP and that of local governments which comprised 8 percent of GDP. ${ }^{25}$ Federal defense spending is more volatile, making up more than 10 percent of GDP in the 1960s and less than 4 percent of GDP at its trough in 2000. Figure 7 shows this breakdown of government spending and highlights the particular importance of local governments to GDP.

Despite its limited direct effect on GDP, federal policy does play a significant role in the path of government consumption and investment through its control over intergovernmental grants to state and local governments as well as regulation of their activities. In this paper, I focus on the effect of intergovernmental grants to large city governments over the period 1971 to 1989 . This time period comes at the tail end of a fifteen-year period of rapid growth in local governments; as seen in Figure 7, the local government contribution to GDP grew from 5.9 percent in 1959 to 8.2 percent by 1974 after which it roughly leveled off. I specifically focus on city governments that had a population of 25,000 or greater in 1972. Collectively, these 837 city governments accounted for roughly 30 percent of all local government expenditure. ${ }^{26}$

City governments provide a broad range of services including police and fire protection, highway construction, sewerage, solid waste management, and utility provision. Their revenues come mainly from a combination of property taxes, intergovernmental revenues, charges and fees, and utility payments. Table 2 shows the breakdown of expenditures and revenues for the 837 cities studied in this paper.

\footnotetext{
${ }^{25}$ Each of these estimates came from averaging over the years 2000-2007, which are the seven most recent years in which the government GDP data were broken up between state and local governments. During the same time period, federal defense consumption and investment made up 4.4 percent of GDP. All components of government together made up 18.6 percent of GDP.

${ }^{26}$ In 1972, the number of governments (with the percent of the local government expenditure that they made up in parentheses) was: 3044 county governments (20\%), 18,517 city and town governments (36\%), 16,991 township governments (3\%), 23,885 special district governments (7\%), and 15,779 school districts $(33 \%)$.
} 
It is worth noting that although education expenditures made up 13 percent of the total expenditures of all of the cities in the sample (see Column (2) of Table 2), less than half of the cities have a positive amount of education expenditures (Column (3) of Table 2). In fact, only 131 of the city governments in the sample are responsible for the K-12 school systems within their city. In the other 706 cities, school districts with separate revenue streams are responsible for funding and organizing K-12 education. When including school districts in the universe of all city, town, and township governments, education made up more than 50 percent of total expenditures in 1977.

\subsection{The Annual Survey of Governments}

Since many of the variables used in the estimation are directly from the Annual Survey of Governments (ASG) produced by the Bureau of the Census, it is worth mentioning a few facts about this survey. In years ending in -2 and -5 , the Census conducts a complete survey of all state, county, city, town, and township governments and school districts. In the intermediate years, they only survey a random sample in which local governments are assigned a probability depending on the area population and other characteristics. Because most large cities are included in the yearly sample with $100 \%$ probability, most of the cities in my sample are represented in every year from 1971-1989. ${ }^{27}$ The exact variables used from the survey will be described in the sections below. All of the finance variables used from the ASG are deflated using the state and local GDP deflator (from the Bureau of Economic Analysis) and are normalized by the city population (from the ASG).

\subsection{Outcome Variables}

The three outcome variables that I will focus on are total city government expenditures, normalized employment, and normalized government employee annual wages. Total expenditures come directly from the ASG and are deflated using the state and local GDP deflator and normalized by the city population. To calculated normalized annual wages, the annual wages are first computed by dividing deflated salaries and wages by total government employment. Multiplying this annual wage by the number of government employees in 1972 gives the normalized wage. The normalized employment variable is arrived at in a similar manner, from multiplying total government employment by the 1972 annual wage. The purpose of these normalizations is to convert the employment and wage variables into

\footnotetext{
${ }^{27}$ The sample consists of 837 cities that had a population of greater than 25,000 in 1972 . All of the cities appear in the sample for the following years: 1972, 1974, 1975, 1976, 1977, 1978, and 1979. For the rest of the years, the number of cities in the sample is shown in parentheses: 1971 (806), 1973 (805), 1980 (834), 1981 (835), 1982 (830), 1983 (830), 1984 (830), 1985 (829), 1986 (829), 1987 (830), 1988 (828), 1989 (803).
} 
expenditure statistics such that the $\beta_{1}$ and $\beta_{2}$ coefficients in Equation (10) can be used to answer the question: How much of each dollar transferred to local governments goes towards employment, and how much goes toward increased wages? I use these normalized variables for ease of interpretation; the message and significance are unchanged when I use non-normalized employment and annual wages in the estimations.

I show results for other outcome variables. Capital outlays, expenditures on employee retirement programs, and own source revenues are taken directly from the ASG. Net new debt issued is calculated by subtracting retired debt from new debt issues, the change in cash and security holdings is calculated from subtracting the previous year's holdings from the current year holdings, and the change in retirement fund cash and security holdings is also calculated by subtracting a lag of total holdings from the holdings in the current year.

\subsection{Union Variables}

The variables used to represent the collective bargaining strength of the public sector come from a dataset collected by Richard Freeman and Robert Valletta at the National Bureau of Economic Research for the years 1959 to 1986, and then extended by Kim Rueben through 1996. In my preferred specification, I use an indicator variable that is equal to zero if the city resides in a state in which there is no provision for public sector collective bargaining or in which collective bargaining is explicitly prohibited. In the cities that reside in a state with an indicator of one, it is either the case that there is a "weak" bargaining provision in which public sector labor has a right to present proposals or to meet and confer or the employer is authorized but not required to bargain, or a "strong" bargaining provision in which the public sector employers have an implied or explicit duty to bargain "in good faith". Figure 8 shows the timing of the legislation passage for this indicator variable.

Figure 9 shows the geographic variation across states in the collective bargaining laws in the year 1972. Expectedly, there appears to be a high correlation between the existence of collective bargaining laws and the party preference of a state. In the robustness section, I will show that controlling for the party of the state governor does not alter the estimated effects of the collective bargaining indicator term.

The Freeman-Valletta dataset and the Rueben extension distinguish between bargaining laws for state employees, municipal police, municipal fire fighters, noncollege teachers, and other local employees. I use the "other local employees" category for the creation of the union indicator variable. The correlation between the legislation for different employee groups is high. ${ }^{28}$

\footnotetext{
${ }^{28}$ Over the time period 1970 to 1989 , the correlation between the indicator representing a weak bargaining provision for "other local employees" and each of the indicators for police employees and fire protection
} 
In the robustness section, I explore the results with two different possible union variables. First, I examine an indicator as to whether union dues are allowed to be subtracted directly from the paychecks of government employees. Second, I create an indicator which represents whether there exists legislation which specifically includes wages in the scope of bargaining.

\subsection{Endogenous Variables}

In all of the instrumental variable regressions, the two endogenous variables are per capita intergovernmental transfers and per capita intergovernmental transfers interacted with the union variable described above. ${ }^{29}$ Intergovernmental transfers are from the ASG.

\subsection{Instruments}

The two instruments used are the general revenue transfers received by the city, and the general revenue sharing funds interacted with the union variable. Because the ASG included a general revenue sharing variable for the years in which the program was in place, I have the exact amounts that the city governments received through the program (as reported in the Census survey by the city governments).

\subsection{Controls}

In almost all regressions, I include city and year fixed effects. Because of this, any city characteristics that are immutable over time cannot be included in the regressions as they are collinear with the government fixed-effects. The baseline controls that I choose to use are those that validate the instrument, as discussed in Section 4.1. The controls that I use are a flexible cubic polynomial in each of the following variables: population, lagged per capita tax revenue, lagged "tax effort" (non-school taxes divided by 1969 per capita personal income), lagged per capita county income, lagged state-level total taxes, lagged state per capita income, and lagged state government individual income taxes. ${ }^{30}$ Tax revenue is from the ASG, 1969 per capita personal income is from the 1970 Dicennial Census, and county personal income is from the Bureau of Economic Analysis (BEA) regional accounts. I

employees is greater than 70 percent. The correlation with the bargaining provisions for noncollege teachers (which is less relevant for the study of general revenue sharing) is 50 percent.

${ }^{29}$ I choose total intergovernmental transfers rather than just federal intergovernmental transfers because of a correlation between general revenue sharing funds and state intergovernmental transfers. The source of this correlation is described in Section 6.1.

${ }^{30}$ For areas smaller than counties, per capita income is released every ten years as a part of the Decennial Census. The measure of local per capita income used in the general revenue sharing formulas through 1982 was therefore the 1969 per capita income published in the 1970 Decennial Census. 
also include a cubic polynomial of lagged own source revenue as a baseline control variable. Although the GRS formula relied on own source taxes, there is evidence that some of the local governments were able to count other types of revenue (fees, for example) in the tax base when the formula was calculated. To fully capture this, I include total own-source revenues as a control.

\subsection{Summary Statistics}

Table 3 shows the summary statistics for the variables used in the estimation equations for the year 1977. On average, cities employeed over 2,000 workers and paid them almost 37,000 (2005) dollars each, although the variation across cities for both of these statistics was substantial. The average city population in my sample was about 100,000, again with considerable variation.

\section{Results}

In this section, I present the baseline results. I first show that the IV regressions have a strong first-stage. I then examine the flypaper effect and find that the city governments increased expenditures by one dollar for every dollar of intergovernmental transfers received. In the next subsection, I explore what the city governments spent the funds on; in particular I examine the employment/wage decision and find that the no-bargaining cities used a significant portion of the transfers to fund new employment whereas the bargaining cities spent on increased wages instead. Finally, I explore the robustness of the results.

\subsection{First-Stage Regressions}

Table 4 displays the first-stage regressions in specifications that do not yet include the indicator for bargaining. The first three columns of Table 4 show OLS regressions of per capita intergovernmental transfers against per capita general revenue sharing receipts, as well as a set of controls including city fixed effects, year fixed effects, and state-time trends. In the first column, I include the full set of baseline controls (without the interactions with the bargaining indicator), in the second column, I exclude the quadratic and cubic polynomials of the allocation variables, and in the third column I do not weight by population. Columns (4) and (5) split the effect on total intergovernmental transfers into the effect on federal

intergovernmental transfers in Column (4) and state intergovernmental transfers in Column (5). 
The first-stage is strong. The coefficient of 1.5 in Column (1) implies that each dollar of per capita general revenue sharing receipts to the city governments led to an increase in per capita intergovernmental transfers of 1.5 dollars. There are two main reasons that the coefficient exceeds one. First, as shown in Column (5), a large part of the excess is due to a positive (albeit insignificant) correlation between the general revenue sharing transfers and state intergovernmental transfers. Because the geographic tiering led to a high correlation between the state government general revenue sharing funds and the local government general revenue sharing funds, one would expect that the state intergovernmental transfers would be correlated with the city general revenue sharing receipts if the state governments "passed on" a certain percentage of revenue that they received from the federal government. Furthermore, it is possible that state governments piggy-backed on the general revenue sharing formula to disperse some of their own intergovernmental transfers, which would also lead to a positive coefficient in Column (5). The positive correlation between the state intergovernmental transfers and the general revenue sharing funds is the primary reason that I chose the endogenous variable to be total intergovernmental transfers rather than just federal intergovernmental transfers.

Second, a reason that the coefficient on federal intergovernmental transfers in Column (4) slightly exceeds one is that a countercyclical revenue sharing program implemented from July 1, 1976 through September 30, 1978 was based on the general revenue sharing formula. Through this program, a total of 3.1 billion dollars was distributed by the federal government to all governments in areas that experienced unemployment rates greater than 4.5 percent. ${ }^{31}$ In the ASG 1978, 733 out of the 837 cities studied in this sample had an unemployment rate of less than 4.5 percent, representing more than 90 percent of the total population in the sample cities. Because the countercyclical revenue sharing funds were positively correlated to the GRS allocations, it is expected that a regression of total intergovernmental transfers on general revenue sharing funds would be greater than 1, albeit not substantially so; at its peak in 1977, the countercyclical program made up roughly only one-quarter of the GRS

\footnotetext{
${ }^{31}$ The funds were only made available if the national unemployment rate, lagged two quarters, was above 6 percent-a constraint that did not bind for the duration of the program. From July 1, 1976 through September 30,1977 , a baseline allocation of $\$ 125$ million per quarter was made available for this program, with an additional $\$ 62.5$ million for each complete one-half percentage point that lagged national unemployment rate was over 6 percent. From July 1, 1977 through September 30, 1978, the baseline allocation continued to be $\$ 125$ million but with an addition $\$ 30$ million per quarter for each one-tenth of a percentage point that the lagged national unemployment rate was above 6 percent. The distribution of these funds were as follows: for each government an index was created by mutliplying the amount that the unemployment rate exceeded 4.5 percent by the government's general revenue sharing allocation. Governments that resided in areas with an unemployment rate less than 4.5 percent were assigned an index of zero. The quarter's allocations were then distributed across governments based on their index. For more details of the formulas see the U.S. Budget (1978), the U.S. Budget (1979), and Government Accounting Office (1977).
} 
transfers. Although the size of the countercyclical revenue sharing program was too small to have a significant macroeconomic impact-research at the time estimated only very small budgetary responses (Gramlich, 1979 and General Accounting Office, 1977)-the structure could be used as a starting point for future countercyclical revenue sharing designs.

Table 5 shows the first-stage results when the indicator for bargaining power is interacted with the intergovernmental and general revenue sharing transfers, increasing both the number of endogenous variables and the number of instruments to two. Column (1) shows the results with the total intergovernmental transfers as the dependent variable, and Column (3) shows the regression with the dependent variable as the interaction of total intergovernmental transfers with the bargaining indicator variable. The first-stage for both endogenous variables remains strong, with F-statistics above 45 for total intergovernmental transfers, and above 16 for the interacted endogenous variable. For both endogenous variables, the coefficient on its corresponding instrument is roughly 1.5 as in Table 4, Column (1), for the same reasons discussed above.

\subsection{The Expenditure Response}

Table 6 shows the OLS and the IV results for total expenditures with five different specifications. All regressions shown include city fixed effects, year fixed effects, fiscal year interacted with year dummies, and are population weighted. Specification (1) does not include the union variable, the union variable interaction with the endogenous variable, state-time trends, or union interaction terms. Specification (2) adds in the state-time trend to the first specification. Specification (3) includes the bargaining variable and the bargaining interaction term without state-time trends or the controls interacted with the bargaining indicator variable, Specification (4) adds in state-time trends, and finally Specification (5) adds in the bargaining interactions with the baseline controls. The coefficients on the interaction terms in Specifications (3)-(5) are measures of the difference between bargaining and no-bargaining cities. To be clear about the interpretation, the coefficients in the OLS panel of Column (3) suggest that for every dollar of intergovernmental revenues, governments in no-bargaining cities spent 97 cents (from the coefficient on the $I G R$ term), and governments in bargaining cities spent 62 cents (which is achieved by adding the coefficient on $I G R, 0.97$, and the coefficient on $I G R *$ Bargaining, -0.35). The coefficient on the $I G R *$ Bargaining term suggests that the difference between the two city types in Specification (3) was significantly different from zero at the $1 \%$ level.

Examination of both panels in Specifications (3) through (5) show that the OLS coefficients are quite similar to the IV coefficients for the no-bargaining cities. However, the 
coefficients for the bargaining cities are higher in the IV regressions than in the OLS regressions, suggesting that there was a downward bias in the OLS results for bargaining cities. A downward bias is unsurprising if the intergovernmental transfers were targeted toward struggling city governments that were in the process of cutting expenditures. The difference between the OLS and the IV results emphasize the need for instrumental variables in this analysis.

The IV coefficients in all of the specifications above are suggestive of a strong expenditure response to the intergovernmental transfers. In the preferred Specification (5), the results imply that for every one dollar of increased intergovernmental transfers, no-bargaining cities increased their expenditures by 0.96 dollars and bargaining cities increased their expenditures by 0.88 dollars. The difference between the expenditure response in bargaining and nobargaining cities is not significant.

One concern with a policy of intergovernmental transfers during recessions is that the recipient governments will use the funds to reduce debt or pad their balances rather than to increase expenditures. Furthermore, although a legislated decrease in taxes might have a stimulative effect, it is often argued that the multiplier is much lower than the multiplier attached to government spending. Thus, it is important to understand whether any of the transfers went towards reduced taxes, reduced debt, or increased savings. To fully map the passage of each dollar received by the city governments, I consider the identity describing the possible effect of IGR on four broad government finance components: total expenditures, own-source revenues, net debt issued, and savings. Equation (13) displays this identity.

$$
I G R=\text { Expenditure }+ \text { Savings }-(\text { Own Revenue }+ \text { NetDebtIssued })
$$

Table 7 maps the effects of a dollar of IGR on these components of government finance; from the identity above, one would expect that the coefficients in the first row should sum to one dollar, and that the coefficients in the second row should sum to zero. The first column of Table 7 shows the effect of IGR on total expenditures, the second on own-source revenue, the third on net debt issued, and the last column on the change in cash and security holdings, an imperfect proxy for savings. Even given this imperfect proxy, the identity of Equation (13) roughly holds. For non-bargaining cities, I find that an increase of one dollar per capita intergovernmental transfers leads to an increase of 0.96 dollars in expenditures, an increase of 0.20 dollars in own source revenues, a decrease of 0.35 dollars in net debt issued, and no change in savings. For bargaining cities, I find that expenditures increase by 88 cents and that own source revenues only increase by 10 cents for each dollar received of intergovernmental transfers. Furthermore, there appears to be a negligible affect on debt issuance and a slightly positive, but insignificant, effect on savings for bargaining cities. 
Although the increase in own-source revenue is not significantly positive, it is meaningfully non-negative; i.e. the results comfortably rule out any substantial decrease in taxes in response to the intergovernmental transfers. In fact, it may be puzzling that the response of own-source revenue appears to be positive, albeit with large standard errors. A positive response of own-source revenue would be consistent with an upturn in the economy due to the increase in government spending, a theory that I will touch upon later in the paper. It would also be consistent with any legislated tax increases that occurred coincidentally with the general revenue sharing transfers. For the moment, the most telling aspect of the result in Column (2) is that I find no evidence that any of the transfers were used to alleviate taxes.

In summary, I find that throughout the 1970s and the 1980s, intergovernmental transfers led to a one-for-one increase in city expenditures and did not lead to any decrease in ownsource revenues. Although these results agree with much of the earlier flypaper literature (see Hines and Thaler, 1995), they are at odds with some of the more recent work on the flypaper effect (see Lutz (2006) and Knight (2002)).

The setting in which an intergovernmental program is studied is crucial to the examination of the expenditure responses of the local governments. For instance, Lutz (2006) found a negligible expenditure response to a large grant increase to New Hampshire school districts in 1999, a time when the unemployment rate in New Hampshire was 2.8 percent. Certainly, the effect of transfers on government expenditures should depend on the type of local government, the geographic location in which the "experiment" occurred, and the state of the economy. Because of this, any evaluation of a policy of intergovernmental transfers ought to rely on analysis conducted over similar settings to the one in which the policy would be implemented.

The setting of the general revenue sharing program makes it particularly suitable for the evaluation of a broad-based federal transfer stimulus policy. First, with federal transfers to all general-purpose governments, the general revenue sharing program is the most comprehensive transfer program in the history of the United States. Second, it was conducted at a time when state and local government budgets were suffering and over a period in which two large recessions occurred. As Figures 10 and 11 show, the national and local unemployment rates were relatively high throughout the entire duration of general revenue sharing; in fact, from 1972 to 1986 the national unemployment rate never fell below 5.7 percent, its average in the post-war period.

There are other reasons that the expenditure effect may have been larger with the general revenue sharing funds than with other transfer programs. The general revenue sharing amounts did depend on the tax-effort of the recipient government. This measure was put in particularly to mute the incentive for the local governments to use the transfers to reduce 
taxes. Although analysis at the time did not find a relationship between the strength of these incentives and legislated tax decreases, ${ }^{32}$ the prospect that these incentives prevented tax offsets is worth exploring more. The fact that the general revenue sharing funds did have a price effect means that the results in this section do not directly test the BradfordOates hypothesis that underlies most flypaper discussions. Furthermore, the general revenue sharing program was highly publicized and governments had to fill out statement of use forms. Starting in 1976, governments also had to hold town meetings to discuss the spending of the funds. Although one might argue that the public awareness should have led to a greater tax offset (under the Bradford-Oates paradigm), another possibility is that the public awareness led to newly publicized programs that would not have been funded otherwise.

\subsection{Employment and Wage Responses}

Table 8 shows the results for the key outcome variables of this paper. Columns (1) and (2) are of particular interest. In bargaining cities, a one dollar increase of intergovernmental transfers leads to a 0.77 dollar increase in wages of existing employees (the sum of 0.21 and 0.56), whereas in non-bargaining cities there is only a 0.21 dollar increase in wages (and insignificant from zero). On the other hand, in bargaining cities, only 0.12 dollars go towards increased employment, while in non-bargaining cities, 0.41 dollars goes to increased employment. For both wage and employment expenditures, the difference between the bargaining and the no-bargaining amounts are significantly different from one another. These results are consistent with the examples drawn in Figure 2 which illustrate how public sector bargaining might lead to a higher wage increase and a smaller employment increase than what would occur in cities without bargaining. There is mild evidence in Column (3) that higher transfers lead to more capital outlays in no-bargaining cities. Column (4) shows the effect on retiree expenditures and Column (5) shows the effect on the change in the cash and securities of the retirement funds (a proxy for retirement fund contributions). Neither of these two variables appears to be significantly affected by an increase in intergovernmental transfers in either type of city.

These results shed light onto the role of actors in the public sector labor markets in affecting the use of intergovernmental transfers. They also emphasize that the study of intergovernmental transfers should not be limited to the expenditure effect (i.e. whether the funds are spent), but also to the type of spending induced by the transfers. If increased wages did not lead to greater hours or higher productivity, the results would be suggestive that the quality of the spending (i.e. the "bang for the buck") increased more in the cities

\footnotetext{
${ }^{32}$ Reischauer, 1975.
} 
that were not subject to collective bargaining laws. However, with these data it is impossible to determine decisively whether or how services were affected unequally in the two types of cities. Because the hours of employees are not measured in these data (or in any available data at the city level over that time period), I cannot test whether the increased wages in bargaining cities funded an equivalent increase in hours to the rise in hours coming from the increased employment in the no-bargaining cities. Furthermore, even if hours were not increased, higher wages may lead to higher productivity or service provision. This is demonstrated in Mas (2006) which shows that New Jersey police officers that won in wage arbitration exhibited higher workplace productivity. Although these caveats make it impossible to determine which type of city increased services more in response to the transfers, the results of this section strongly suggest that there is a difference in the way in which the funds were used.

Interactions with Unemployment Rate Table 9 shows the results when the intergovernmental transfers are interacted with an indicator representing the state of the economy. Specifically, the measure I use in the table below is whether the state unemployment rate is more than 2 percentage points above the period average. Other measures of "bad economic times" yield similar results. The first and second rows represent the response to IGR in no-bargaining cities to "bad times" and "good times", respectively, while the third and the fourth rows show the difference between the response in bargaining cities and no-bargaining cities in "bad times" (Row 3) and "good times" (Row 4). Columns (1) and (3) show that the expenditure and the wage responses do not appear to change substantially in either time frame. However, the difference in the transfer-induced employment increase between bargaining and no-bargaining cities appears to shrink during "good" times (when unemployment is less than two percentage points above the period average). The standard errors in Column (4) are too large to draw any firm conclusions about the effect on capital outlays.

The fact that the difference between the employment response in bargaining and the no-bargaining cities shrinks in times when the unemployment rate is lower than average is particularly interesting. To explain why this might occur, I consider the theory in the public sector union literature that public sector unions can use their political strength to shift out the demand for public employment (Freeman (1986), Marlow and Orzechowski, 1996)), but I assume that their ability to do so depends on the state of the economy. This could occur if the union's political voice is drowned out by the many disgruntled voices of citizens at times when the city government is losing revenues and cutting expenditures. In "good" times, when the union succeeds in shifting out the demand curve (and for simplicity, I assume they achieve this goal after the collective bargaining negotiations are carried out), 
city governments will see a larger rise in employment than they would otherwise. This is pictured in Figure 12.

\subsection{Robustness}

Table 10 explores the robustness of the total expenditure, normalized wage, and normalized employment results. The first column shows the results of the preferred specification shown in Table 5, Column (5) and Table 8, Columns (1) and (2). Columns (3) and (4) show the results with the different measures of bargaining strength: Column (3) uses an indicator for whether the bargaining laws (if they exist) specifically include wages in the scope of bargaining, and Column (4) uses an indicator for whether union dues can be automatically deducted from employee payrolls. The fourth column drops the five largest cities in $1972 .{ }^{33}$ Finally, Column (5) shows the unweighted results. The expenditure results are robust to all of these changes. The normalized wage and normalized employment results are fairly robust to changing the measure of bargaining strength, but are not robust to dropping the five largest cities or running unweighted regressions. Together, the five most populous cities make up 20 percent of the sample population in 1972; it is unsurprising that removing them could have substantial effects on the coefficient estimates or that these would move the results in the direction of the unweighted results. Since I seek to find the effect of the bargaining on large cities, conceptually these cities do belong in the sample. Furthermore, to the extent that there may exist fixed costs to unionization (see Trejo (1991)), there is not an a priori reason that one would expect that the effect of bargaining would be the same in a population-weighted regression as in an unweighted regression. In fact, Columns (4) and (5) provide suggestive evidence that Trejo's argument of fixed costs in union power is correct; the bargaining laws appear to have less power in smaller cities.

In Table 11, I explore the possibility that the union variable is actually capturing political views rather than collective bargaining strength, as well as the possibility that the dependence of the general revenue sharing on higher order interactions of its correlates may be driving the results. In Column (1), I show the results of the preferred specification. In Column (2), I add as a control an indicator variable for whether a democratic governor is in office, and in Column (3) I also interact this indicator variable with the general revenue sharing funds. Columns (2) and (3) specifically address the concern that the bargaining indicator variable is capturing the politics of a state (and its cities) rather than the strength of public sector unions within the state. The results show that the coefficients on the inter-

\footnotetext{
${ }^{33}$ These cities, their populations, and their population percent of the total 1972 sample population are: New York (7.9 million, 8.9\%), Chicago (3.4 million, 3.8\%), Los Angeles (2.8 million, 3.2\%), Philadelphia (2.0 million, $2.2 \%$ ), and Detroit (1.5 million, $1.7 \%$ ).
} 
action of general revenue sharing with the bargaining indicator variable are little changed, even when I include the indicator of the party of the governor interacted with the general revenue sharing funds, as in Column (3). Legislation such as that surrounding public sector collective bargaining is often politically hard to change once in place, leading to legislative persistence over time even as the party preferences of the states change.

In Column (4), I include the "three-factor" formula at the city level; i.e. the product of population, tax effort, and inverse per capita income. ${ }^{34}$ In Column (5), I also include the "three-factor" formula at the state level. These last two columns deal with the concern that the cubic polynomials of the GRS-correlated variables do not fully capture their direct impact on the outcome variables. Including more interactions of these variables yields almost no difference in the estimation of the coefficients of interest. These results are supportive of the conclusion that the flexible cubic polynomials absorbed an appropriate amount of the general revenue sharing variation.

\section{Intergovernmental Transfers and Aggregate Economic Activity}

My results above show that the general purpose transfers in the 1970s and the 1980s led to approximately one-for-one increases in local government expenditure. At first blush, these findings of a strong expenditure effect are supportive of a stimulative policy of transferring funds to local governments; at least the highly debated question of whether the funds would be spent appears to be resolved for the context I study in this paper. Any complete evaluation of a transfer policy, however, would have to include a consideration of the output multipliers attached to local government spending. Since the results of Section 6.3 find that there exists an institutional friction, public sector bargaining, that determines whether federal transfers are applied to higher wages or new employment in large cities, the question of whether these two types of spending could have different effects on the surrounding private economy is crucial. In this section, I explore the possibility that the types of spending produced by transfers to bargaining and no-bargaining cities are associated with different output multipliers.

A clear connection has been shown between an individual's income and their marginal propensity to consume (Parker, Souleles, Johnson, McClelland, 2011). If government spending on employment gives income to a person who would have otherwise been unemployed as opposed to increasing the wages of an already employed individual, one would expect that

\footnotetext{
${ }^{34}$ Because per capita income is not annually available at the city level, I interact with per capita income at a county level.
} 
the marginal propensity to consume of the former would be greater than the latter. If this is the case, theory would suggest that the multiplier would be higher when the spending is on employment rather than wages. ${ }^{35}$ This argument depends on the idea that increasing the number of government jobs would actually reduce unemployment in the local economy. At times of full employment, this is an unreasonable assumption; government spending on increased employment would crowd out employment in the private sector. However, when the unemployment rate is above the natural rate of unemployment and there is excess capacity in the economy and slack demand, government job creation is more likely to have an immediate effect on unemployment. This description is a much closer approximation to the time period in which the general revenue sharing was carried out.

\subsection{Empirical Strategy and Results}

In this section, I explore the possibility that the multiplier on the types of expenditures generated in bargaining and no-bargaining cities differ from one another. Note that although the theory above focuses on the distinctions that might arise due to differential spending on new employment versus existing wages, my methodology only allows me to test the difference between bargaining and no-bargaining city spending. To the extent that the spending differs in other ways (such as the suggestive evidence that no-bargaining cities spend more of the transfers on capital outlays), I will not be able to determine which particular differences are affecting any divergence in multipliers.

Because city-level private employment and income data are not available, I use annual county employment and income data from the Bureau of Economic Analysis regional accounts. The data used are from BEA Table CA04. As described above for non-ASG variables, I adjust these data to match the timing of the fiscal years in each city, and I deflate the income data using the GDP deflator.

I examine the effect of intergovernmental transfers on private employment and income. The government finance data are not ideally suited to study the effects on the private economy. Because the macroeconomic data are only available at the county level while the intergovernmental transfer data are at the city level, I cannot simply replace the outcome variables in Equation (10) with the county BEA data. ${ }^{36}$ I deal with the city and county disparities in three ways. First, I limit my analysis to cities that make up at least 50 percent of their corresponding county, which dramatically shrinks the sample from 837 cities to

\footnotetext{
${ }^{35}$ The connection between the marginal propensity to consume and the output multiplier is discussed extensively in the New-Keynesian literature (see, for example, Gali, Lopez-Salido, Valles, 2007).

${ }^{36}$ County area data are only available in the Annual Survey of Governments in the Census years ending in -2 and -7 .
} 
206 cities. Second, I normalize the county variables by county population rather than city population. Finally, to account for city-county differences in per capita intergovernmental transfers, I scale the endogenous variables, $I G R_{i t}$ and $I G R_{i t} * U_{i t}$, by the county-city $I G R$ ratio in the most recent government census year (i.e. 1972, 1977, 1982, or 1987).

Table 12 shows the crosswalk from the city employment results initially reported in Table 8 to the macroeconomic total employment results. Column (1) shows the results achieved when using the normalized employment variable as shown in Table 8. Column (2) changes the dependent variable to employment per 1000 population, and the results imply that a transfer of 1,000,000 (2005) dollars led to an increase of 10.8 jobs in no-bargaining cities, and 2.6 government jobs in bargaining cities. Column (3) limits the sample to cities that make up at least 50 percent of their county. The findings are similar to that of Column (2), although the standard errors have increased due to the smaller sample size.

Finally, Columns (4) and (5) have per capita total county employment as the dependent variable and scale the endogenous variables as discussed above. Column (4) implies that 1,000,000 dollars of general revenue sharing receipts to all of the local governments in a county yield an increase of 9.9 government jobs in no-bargaining cities and a decrease of 2.8 jobs in bargaining cities. If the response of all of the governments mirrors the response of the city government, one would expect that the coefficients in Columns (3) and (4) should match. Indeed, they are within the same range, and a difference of zero cannot be rejected. It is concerning that the county government employment data appears to predict a decrease in government employment in response to the intergovernmental transfers. However, wide standard errors make it impossible to reject zero or a positive response. The most significant result in Column (4) is the difference between the government employment produced in bargaining and no-bargaining cities.

Column (5) shows the main test of interest, which is the effect of the intergovernmental transfers on total employment within the county. There appears to be a large response in no-bargaining cities, and a slightly negative response (although zero cannot be rejected) in bargaining cities. Again, the most significant result is the difference between bargaining and no-bargaining cities, which is significant at the five percent level.

The level of the coefficients in Table 12 Column (5) implies that 1,000,000 of (2005) dollars of transfers led to an increase of 32 total jobs in no-bargaining counties, and a decrease of 13 jobs in bargaining counties. One way to interpret these coefficients is to assume that the employee compensation is equal to the employee's marginal product and to multiply the jobs created by the average employee compensation in 1977 (to take an intermediate year), which was 39,000 dollars. ${ }^{37}$ This yields a relative increase in GDP of about 1,200,000 (2005) dollars

\footnotetext{
${ }^{37}$ To arrive at this average compensation number, I used figures from the Bureau of Economic Analysis
} 
for every 1,000,000 received in transfers, which would imply a multiplier of roughly 1.2 in no-bargaining cities (and a slightly negative multiplier-insignificant from zero-in bargaining cities). These multiplier estimates are within the bounds calculated in recent empirical work; however, the large standard errors around the point estimates prevent the possibility of firm conclusions about the levels of multipliers in this exercise. ${ }^{38}$ Indeed, the key result is the difference between the multipliers in bargaining and no-bargaining cities.

Table 13 explores the robustness of the total employment results in Table 11, Column (5). In Column (2), the sample is expanded to include cities that make up at least 30 percent of the counties in which they reside, and in Column (3), the sample is restricted to only include those cities that make up at least 85 percent of their counties. In Column (4), the state-time trend is removed, and in Column (5), the largest five cities are removed from the preferred specification. The results are not robust to all of these changes. In particular, the standard errors are too large in Columns (3) and Columns (5) to infer anything meaningful from the difference in the response in bargaining and no-bargaining locales, although it is notable that the sign of the difference in the multipliers switches in Column (5). In Columns (2) and (4), the difference between the two types of city remains significantly negative at at least the 10 percent level. Overall, the (mostly) negative point estimates in the second row are suggestive of the idea that the multipliers on intergovernmental transfers to no-bargaining cities are higher than those to bargaining cities, which would be consistent with the hypothesis that spending on new employment stimulates the private economy more successfully than spending on wages. However, due to large standard errors and fluctuations across specifications, these data are not able to fully weigh in on this hypothesis. I present these employment results to motivate further exploration into how the public sector labor markets may affect the stimulative output multipliers associated with federal government transfers to state and local governments.

\section{Conclusion}

In this paper, I revisit a large intergovernmental grant program in which the federal government transferred funds to all general-purpose state and local governments. I find, contrary to some recent research, that the recipient city governments spent almost all of the funds

NIPA accounts. Specifically, I divided the total compensation of employees in 1977 from Table $6.2 \mathrm{~B}$ by the total number of full-time equivalent employees in Table 6.5B. Lastly, I multiplied by the GDP price index from Table 1.1.4.

${ }^{38} \mathrm{I}$ also examined the effect of the general revenue sharing transfers on per capita personal income. However, the standard errors in these calculations were too large to draw any meaningful conclusions; neither the multiplier levels nor the differences between bargaining and no-bargaining cities were significantly different from zero in any specification. 
that they received. This finding, on the face, is supportive of a stimulative policy of transferring funds to city governments, at least during tumultuous economic times similar to those of the 1970s and the 1980s. However, I discuss the possibility that the "type" of government spending produced by the transfers may be as important as the fact of the spending itself when evaluating a policy of intergovernmental transfers. Motivated by the literature on public sector unions, I explore whether the type of spending is affected by the existence of public sector collective bargaining legislation. I find that the cities subject to state-level pro-union bargaining laws spent a significant portion of the transfers on increased wages of existing employees, while cities without such laws spent a larger fraction of the funds on new employment. Finally, I explore the possibility that these two types of spending have differential effects on the private economy.

This paper brings together a combination of macroeconomics and public finance topics that have rarely been linked in previous research. The public finance literature on intergovernmental grants has tended to focus on the impacts of grants on the hiring and spending behavior of the government bodies without considering the implications that this changed behavior may have on the private economy. This issue becomes particularly important in a recessionary environment when national governments are weighing their countercyclical options at the same time that their subnational governments are responding to their own fiscal pressures. Subnational governments play a substantial role in most advanced and emerging countries; the ratio of their expenditures to total government expenditures hovers between 30 to 50 percent for many countries, and exceeds 50 percent in at least Canada, Denmark, Switzerland, and the United States (Rodden, 2004). Yet, there has been little work done to understand the effectiveness of leveraging these subnational governments to stimulate the economy. More broadly, the general connection between subnational budgets and the business cycle warrants further investigation. While there has been some work using aggregate time series on the extent to which subnational government variables move with or against the business cycle (Hines, 2010, Rodden and Wibbels, 2010), this paper highlights the fact that aggregate time series may mask some interesting heterogeneity at the local government level. Exploring this set of questions using disaggregated data will be fruitful for future research.

From the macroeconomics side, the literature on the effect of government spending tends to ignore the political economy frictions that influence the "quality" or type of government spending that is feasible. The institutional frictions that influence the direction of spending may have a large impact on the ultimate effectiveness of a temporary expansion of government. The findings of this paper suggest a natural path for future exploration; namely, probing into the possible multiplier differences that may arise from government spending on 
new employment versus government spending on increased wages. Furthermore, although this paper focuses on the local government sector of the United States, the large size of public sector unions in other advanced economies suggests that the relevance of this line of future research may apply to other countries.

Finally, an implication of my findings is that the provision of government services may vary depending on the strength of the public sector unions. If employment is a measure of the quantity of services provided, my results would imply that transfers to no-bargaining cities yield higher level of public services than transfers to bargaining cities. These results suggest that research on the flypaper effect may be misleading; local government expenditures do not link directly to the provision of public services. 


\section{Appendix}

In this appendix, I describe the adjustments that I make to account for the fact that the Annual Survey of Governments covers a variation of fiscal years across cities.

City governments vary substantially in the timing of their fiscal years reported in the ASG. Naively using year fixed effects corresponding to the years in the ASG to pick up macroeconomic events would be incorrect. Local governments filling out the ASG in a particular year are instructed to report on their fiscal year that ended between July of the previous year and June of the survey year. For example, in the 1973 ASG, the finance variables of cities that have fiscal years from July to June will cover the fiscal year July 1972 to June 1973. On the other hand, cities with fiscal years from August to July will cover August 1971 to July 1972 in the same 1973 survey. The ASG year fixed effect will therefore not capture the macroeconomic events corresponding to a particular year. Furthermore, other variables such as the price index used to deflate the nominal finance figures must correspond to the time period of the cities' finance variables.

The figure below shows the timing of the initial general revenue sharing fund disbursements as well as the timing of the fiscal years covered by the 1973 and the 1974 ASGs. The numbers in the left column underneath the timeline represent the number of cities in the sample with the corresponding fiscal year timing to the right of the number. There are 339 cities that have a fiscal year that end in December, and 308 cities that have a fiscal year that end in June. As shown in the figure, the initial funds were disbursed in December 1972. This disbursement should show up in the 1973 ASG for cities that have fiscal years ending in December through June, and will show up in the 1974 ASG for all other cities.

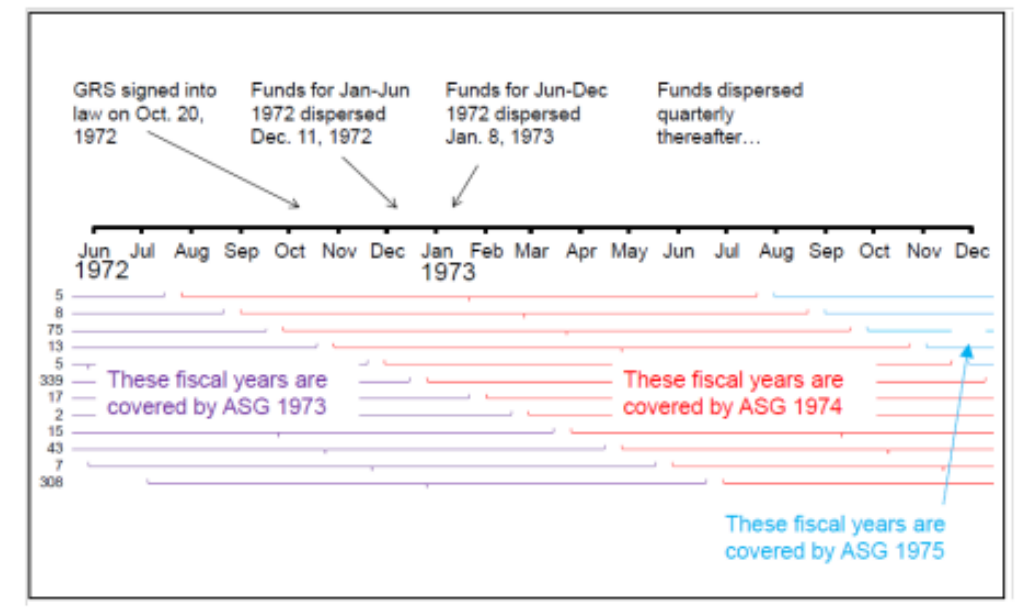

There are two main issues that need to be addressed in this analysis. The first is that the year fixed effects need to be adjusted so as to correctly capture the timing of the nationwide 
macroeconomic events. The second is that the non-ASG variables must be adjusted to match the fiscal years represented by the cities.

Accomplishing the first task is easy; rather than only including year fixed effects, I also include an indicator for the fiscal year timing interacted with year dummies-which means that, in essence, I allow the year fixed effect to depend on the fiscal year timing of the particular government. For instance, if there was a macroeconomic event that occurred in January 1973 that caused a significant drop in city government revenue, we would expect to observe that drop in the 1973 ASG for all cities that have a fiscal year ending in the months from January to June, and in the 1974 ASG for cities that have a fiscal year ending in a month after June. Allowing the year fixed effect to depend on the fiscal year ending month will allow this drop to be distributed as it should be.

To accomplish the second task, I must adjust all non-ASG variables to match the timing of the specific city to which the variable is "applied". All non-ASG variables are adjusted in the following way:

$$
\begin{aligned}
& Y_{i t}=Y_{i t-2} *\left(1-\frac{f y}{12}\right)+Y_{i t-1} *\left(\frac{f y}{12}\right) \quad \text { if } f y>6 \\
& Y_{i t}=Y_{i t-1} *\left(1-\frac{f y}{12}\right)+Y_{i t} *\left(\frac{f y}{12}\right) \quad \text { if } f y \leq 6
\end{aligned}
$$

where $f y$ is the fiscal year ending month, and $Y_{i t}$ is the non-ASG variable to be adjusted. The non-ASG variables described in the data sections above that are adjusted are the GDP deflators and the BEA per capita county income. 


\section{References}

Ashenfelter, Orley and George E. Johnson, "Bargaining Theory, Trade Unions, and Industrial Strike Activity," American Economic Review, Vol. 59, No. 1, pp. 35-49, 1969.

Allen, Steven G., "Unions and Job Security in the Public Sector," in When Public Sectors Unionize, pp. 271-304, 1988.

Bennett, James T. and William P. Orzechowski, "The Voting Behavior of Bureaucrats: Some Empirical Evidence," Public Choice, Vol. 41(2), pp. 271-283, 1983.

Blanchard, Olivier and Lawrence Summers, "Hysteresis and the European Unemployment Problem," in NBER Macroeconomics Annual 1986, Volume 1, ed. Stanley Fischer, MIT Press, pp. 15-90, 1986.

Bradford, David and Wallace E. Oates, "The Analysis of Revenue Sharing in a New Approach to Collective Fiscal Decisions", Quarterly Journal of Economics, Vol. 85, No. 3, 1971.

Chernick, Howard, "An Economic Model of the Distribution of Project Grants" in Fiscal Federalism and Grants-in-Aid, Peter Mieszkowski and William Oakland eds. Washington D.C.: Urban Institute, 1979.

Chodorow-Reich, Gabriel, Laura Feiveson, Zach Liscow, and William Woolston, "Does State Fiscal Relief During Recessions Increase Employment? Evidence from the American Recovery and Reinvestment Act," American Economic Journal: Economic Policy, Vol. 4, No. 3, 2012.

Clemens, Jeffrey and Stephen Miran, "The Effects of State Budget Cuts on Employment and Income," Working Paper, 2011.

Cogan, John and John Taylor, "What the Government Purchases Multiplier Actually Multiplied in the 2009 Stimulus Package," NBER Working Paper 16505, 2010.

Conley, Timothy and Bill Dupor, "The American Recovery and Reinvestment Act: Solely a Government Jobs Program?" Working Paper, 2012.

Courant, Paul N., Edward M. Gramlich, and Daniel L. Rubinfeld, "Public Employee Market Power and the Level of Government Spending," American Economic Review, Vol. 69, No. 5, pp. 806-17, 1979. 
Dommel, Paul, The Politics of Revenue Sharing (Bloomington: Indiana University Press), 1974.

Dunlop, John T., Wage Determination Under Trade Unions, Macmillan Col, New York, 1944.

Farber, Henry S., "The Analysis of Union Behavior," in Handbook of Labor Economics, Volume II, ed. O. Ashenfelter and R. Layard, Elsevier Science Publishers, Chapter 18, 1986.

Filimon, Radu, Thomas Romer, and Howard Rosenthal, "Asymmetric Information and Agenda Control," Journal of Public Economics, Vol. 17 (February), pp. 51-70, 1982.

Finn, Mary G., "Cyclical Effects of Government's Employment and Goods Purchases." International Economic Review 39(3): 635-657, 1998.

Frandsen, Brigham R., "The Effects of Public Sector Collective Bargaining Rights," unpublished manuscript, 2011.

Freeman, Richard B. "Unionism Comes to the Public Sector," Journal of Economic Literature, Vol. 24(1), pp. 41-86, 1986.

Freeman, Richard B. and Robert G. Valletta, "The Effects of Public Sector Labor Laws on Labor Market Institutions and Outcomes," in When Public Sector Workers Unionize, Ed. Richard Freeman and Casey Ichniowski, University of Chicago Press, 1988.

Gali, Jordi, J. David Lopez-Salido, and Javier Valles, "Understanding the Effects of Government Spending on Consumption," Journal of European Economic Association, Vol. 5(1), pp. 227-270, 2007.

General Accounting Office, United States, "Report to Congress: Antirecession AssistanceAn Evaluation." PAD-78-20, November 29, 1977.

Gramlich, Edward, "Intergovernmental Grants: A Review of the Empirical Literature," in W.E. Oates (ed.), The Political Economy of Federalism, Lexington, MA: Lexington Books, pp. 219-240, 1977.

Gramlich, Edward, "Stimulating the Macro Economy Through State and Local Governments," The American Economic Review, Vol. 69, No. 2, 1979.

Gregory, Robert G. and Jeff Borland, "Recent Developments in Public Sector Labor Markets," in Handbook of Labor Economics, Volume 3, ed. O. Ashenfelter and David Card, pp. 3573-3630, 1999. 
Hines, James R. and Richard H. Thaler, "Anomalies: The Flypaper Effect," Journal of Economic Perspectives, Vol. 9, No. 41995.

Hines, James R., "State Fiscal Policies and Transitory Income Fluctuations," Brookings Papers on Economic Activity, The Brookings Institution, Vol. 41, No. 2, pp. 313-350, 2010.

Hirsch, Barry T. and David A. Macpherson, "Union Membership and Coverage Database from the Current Population Survey: Note," Industrial and Labor Relations Review, Vol. 56, No. 2, pp. 349-54, 2003.

Hoxby, Caroline M, "How Teachers' Unions Affect Education Production," The Quarterly Journal of Economics, Vol. 111, pp. 671-718, 1996.

Inman, Robert, "The Flypaper Effect," NBER Working Paper 14579, December 2008.

Joint Committee on Internal Revenue Taxation, "General Explanation of the State and Local Fiscal Assistance Act and the Federal-State Tax Collection Act of 1972: H.R. 14370, 92D Congress, Public Law 92-512," U.S. Government Printing Office, Washington, D.C. 1973.

Knight, Brian, "Endogenous Federal Grants and Crowd-out of State Government Spending: Theory and Evidence from the Federal Highway Program", American Economic Review, Vol. 92, No. 1, pg. $71-92,2002$.

Lewis, Gregg, "Union/Nonunion Wage Gaps in the Public Sector," Journal of Labor Economics, Vol. 8(1), pp. S260-S328, 1990..

Lutz, Byron, "Taxation with Representation: Intergovernmental Grants in a Plebiscite Democracy," Finance and Economics Discussion Series, Divisions of Research 8$\}$ Statistics and Monetary Affairs, Federal Reserve Board, 2006.

Maguire, Steven, "General Revenue Sharing: Background and Analysis," CRS Report for Congress, The Library of Congress, May 23, 2003.

Markusen, Ann R., Annalee Saxenian, and Marc A. Weiss, "Who Benefits from Intergovernmental Transfers?" Publius Vol. 11, No. 1, pp. 5-35, 1981.

Marlow, Michael L. and William Orzechowski, "Public Sector Unions and Public Spending," Public Choice, Vol. 89, pp. 1-16, 1996. 
Mas, Alexandre, "Pay, Reference Points, and Police Performance," The Quarterly Journal of Economics, Vol. 121, No. 3, pp. 783-821, 2006.

Pappa, Evi, "The Effects of Fiscal Shocks on Employment and the Real Wage." International Economic Review 50(217-243): 400-421, 2009.

Parker, Jonathan, Nicholas Souleles, David Johnson, and Robert McClelland, "Consumer Spending and the Economic Stimulus Payments of 2008," Working Paper, 2011.

Poterba, Jim, "State Responses to Fiscal Crises: the Effects of Budgetary Institutions and Politics," Journal of Political Economy 102(4). Chicago: University of Chicago press. 1994.

Reder, M.W.,"The Theory of Employment and Wages in the Public Sector," in Labor in the Public and Nonprofit Sectors, Ed. D. Hamermesh, Princeton University Press, Princeton, NJ, pp. 1-48, 1975.

Rodden, Jonathan, "Comparative Federalism and Decentralization: On Meaning and Measurement," Comparative Politics, Vol. 36, No. 4, pp. 481-500, 2004.

Rodden, Jonathan and Erik Wibbels, "Fiscal Decentralization and the Business Cycle: An Empirical Study of Seven Federations," Economics \& Politics, Vol. 22, No. 1, pp. 37-67, 2010.

Ross, Arthur M. Trade Union Wage Policy. Berkeley: University of California Press, 1948.

Saltzman, Gregory M. "Public Sector Bargaining Laws Really Matter: Evidence from Ohio and Illinois," in When Public Sector Workers Unionize, Ed. Richard Freeman and Casey Ichniowski, University of Chicago Press, 1988.

Singhal, Monica, "Special Interest Groups and the Allocation of Public Funds", Journal of Public Economics, Volume 92, Issues 3-4, 2008.

Trejo, Stephen, "Public Sector Unions and Muncipal Employment," Industrial and Labor Relations Review, Vol. 45(1), pp. 166-180, 1991.

United States Bureau of the Census, "Labor-Management Relations in State and Local Governments," Washington: GPO. 1972, 1977, 1982, 1987. 
United States. Office of Management and Budget. Budget of the United States Government: Fiscal Year 1978. Washington: GPO, 1978.

United States. Office of Management and Budget. Budget of the United States Government: Fiscal Year 1979. Washington: GPO, 1979.

Valletta, Robert G. "Union Effects on Municipal Employment and Wages: A Longitudinal Approach," The Journal of Labor Economics, Vol. 11(3), pp. 545-574, 1993.

Wynne, Mark, "The Analysis of Fiscal Policy in Neoclassical Models." Working paper 9212, Federal Reserve Bank of Dallas, 1992.

Zax, Jeffrey S. and Casey Ichniowski, "The Effect of Public Sector Unions on Payroll, Employment, and Municipal Budgets," in When Public Sector Workers Unionize, Richard B. Freeman and Casey Ichniowski, eds., National Bureau of Economic Research and the University of Chicago Press, 232-361, 1988. 


\section{Tables}

Table 1: Federal Funds Transferred through the GRS program

\begin{tabular}{|c|c|c|c|c|c|c|}
\hline \multirow{3}{*}{ Year } & \multirow[b]{3}{*}{$\begin{array}{c}\text { Millions of } \\
\text { current dollars }\end{array}$} & \multirow[b]{3}{*}{$\begin{array}{l}\text { Millions of } \\
2005 \text { dollars }\end{array}$} & \multirow[b]{3}{*}{$\begin{array}{l}\text { Percent of } \\
\text { GDP }\end{array}$} & \multirow{2}{*}{\multicolumn{2}{|c|}{$\begin{array}{c}\text { (4) } \\
\text { Percent of Gov't Expenditures }\end{array}$}} & \multirow[b]{3}{*}{$\begin{array}{l}\text { Per Capita, } \\
2005 \text { Dollars }\end{array}$} \\
\hline & & & & & & \\
\hline & & & & $\begin{array}{c}\text { State } \\
\text { Governments }\end{array}$ & $\begin{array}{c}\text { Local } \\
\text { Governments }\end{array}$ & \\
\hline 1972 & 5,300 & 25,364 & $0.43 \%$ & $2.79 \%$ & $3.56 \%$ & 120.8 \\
\hline 1974 & 6,125 & 24,529 & $0.41 \%$ & $2.62 \%$ & $3.25 \%$ & 114.7 \\
\hline 1976 & 6,500 & 22,326 & $0.36 \%$ & $2.23 \%$ & $2.80 \%$ & 102.4 \\
\hline 1978 & 6,850 & 20,731 & $0.30 \%$ & $2.02 \%$ & $2.48 \%$ & 93.1 \\
\hline 1980 & 6,279 & 15,697 & $0.23 \%$ & $1.19 \%$ & $2.06 \%$ & 69.1 \\
\hline 1982 & 4,567 & 9,761 & $0.14 \%$ & $0.00 \%$ & $1.79 \%$ & 42.1 \\
\hline 1984 & 4,567 & 8,948 & $0.12 \%$ & $0.00 \%$ & $1.55 \%$ & 37.9 \\
\hline 1986 & 3,425 & 6,276 & $0.08 \%$ & $0.00 \%$ & $0.95 \%$ & 26.1 \\
\hline
\end{tabular}

Notes: Government expenditures in Columns (4) and (5) exclude intergovernmental transfers. The GDP state and local price deflator are used to deflate data in Columns (2) and (6). General revenue sharing data are from Maguire (2009). GDP data are from the Bureau of Economic Analysis NIPA Tables 1.1.4, 1.1.5, 3.20, and 3.21. 
Table 2: City Finance Statistics

\begin{tabular}{|c|c|c|c|}
\hline & $\begin{array}{c}\text { Total } \\
\text { (Millions of \$) } \\
\text { (1) }\end{array}$ & $\begin{array}{l}\text { Percent of Total } \\
\text { (2) }\end{array}$ & $\begin{array}{c}\text { Median Percent of } \\
\text { Total } \\
\text { (3) }\end{array}$ \\
\hline & \multicolumn{3}{|c|}{ Expenditures } \\
\hline Total Expenditures & 57,507 & 100 & 100 \\
\hline General Expenditures & 47,007 & 81.7 & 88.2 \\
\hline Salaries and Wages & 23,041 & 40.1 & 42.1 \\
\hline Capital Outlays & 8,685 & 15.1 & 16.1 \\
\hline \multicolumn{4}{|l|}{ COMPONENTS } \\
\hline Education & 7,279 & 12.7 & 0 \\
\hline Police & 5,011 & 8.7 & 11.2 \\
\hline Welfare & 4,561 & 7.9 & 0 \\
\hline Fire Protection & 2,903 & 5 & 7.5 \\
\hline Sewerage & 2,850 & 5 & 4.4 \\
\hline Interest Payments & 2,885 & 5 & 3.7 \\
\hline Highways & 2,844 & 4.9 & 8.3 \\
\hline Parks & 2,012 & 3.5 & 4.4 \\
\hline Housing and Community Dev. & 1,700 & 3 & 0.1 \\
\hline Solid Waste Management & 1,526 & 2.7 & 3.2 \\
\hline Central Staff Services & 930 & 1.6 & 2.6 \\
\hline Health & 871 & 1.5 & 0.3 \\
\hline Financial Administration & 767 & 1.3 & 1.7 \\
\hline Public Buildings & 687 & 1.2 & 1.1 \\
\hline Libraries & 570 & 1 & 1 \\
\hline Air Transportation & 559 & 1 & 0 \\
\hline Utilities (Non-General) & 8,323 & 14.5 & 10.1 \\
\hline \multirow[t]{2}{*}{ Insurance Trust (Non-General) } & 2,144 & 3.7 & 0.3 \\
\hline & \multicolumn{3}{|c|}{ Revenues } \\
\hline Total Revenue & 59,933 & 100 & 100 \\
\hline Property Tax & 12,942 & 21.6 & 21.6 \\
\hline State IGR & 12,614 & 21.0 & 13.3 \\
\hline Charges and Misc. Revenue & 8,026 & 13.4 & 15.5 \\
\hline Federal IGR & 7,556 & 12.6 & 8.3 \\
\hline Sales and Gross Receipts Tax & 4,749 & 7.9 & 5.3 \\
\hline Income Tax & 2,880 & 4.8 & 0.0 \\
\hline Utilities (Non-General) & 7,243 & 12.1 & 9.0 \\
\hline Insurance Trust (Non-General) & 1,135 & 1.9 & 0.0 \\
\hline
\end{tabular}

Notes: Data from the 1977 Census of Governments. 
Table 3: Summary Statistics - 1977

\begin{tabular}{|c|c|c|c|c|c|}
\hline & Mean & 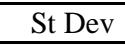 & Min & Median & $\overline{M a x}$ \\
\hline \multicolumn{6}{|l|}{ Dependent Variables } \\
\hline Total Expenditure (pc) & 1,451 & 938 & 203 & 1,148 & 8,098 \\
\hline Total Revenue - Own Sources (pc) & 1,040 & 658 & 119 & 828 & 4,629 \\
\hline Net Debt Issued (pc) & 89 & 347 & -742 & -15 & 3,540 \\
\hline Change in Cash Securities (pc) & 129 & 377 & $-1,849$ & 73 & 3,925 \\
\hline Salaries and Wages (pc) & 579 & 402 & 35 & 441 & 3,728 \\
\hline Annual Wage & 36,984 & 9,694 & 2,819 & 36,130 & 95,243 \\
\hline Total Employees & 2,208 & 12,788 & 24 & 664 & 350,302 \\
\hline Capital Outlays (pc) & 270 & 277 & 0 & 179 & 2,126 \\
\hline Retirement Expenditures (pc) & 19 & 38 & 0 & 3 & 405 \\
\hline Change in Ret Securities (pc) & 69 & 163 & $-1,339$ & 0 & 1,781 \\
\hline \multicolumn{6}{|l|}{ Endogenous Variables } \\
\hline IGR (pc) & 438 & 530 & 28 & 296 & 10,191 \\
\hline Fed IGR (pc) & 174 & 216 & 0 & 104 & 3,425 \\
\hline State IGR (pc) & 240 & 429 & 0 & 151 & 9,693 \\
\hline \multicolumn{6}{|l|}{ Instrument and Control Variables } \\
\hline GRS (pc) & 53 & 27 & 0 & 48 & 174 \\
\hline Total Taxes (pc) & 516 & 390 & 46 & 396 & 3,402 \\
\hline Tax Effort (\%) & 4 & 2 & 0 & 3 & 19 \\
\hline County Income (pc) & 19,326 & 3,303 & 9,528 & 19,152 & 32,482 \\
\hline Population & 105,516 & 322,489 & 21,042 & 48,327 & $7,481,613$ \\
\hline State Income (pc) & 18,810 & 2,335 & 12,593 & 18,565 & 31,779 \\
\hline State Total Taxes (pc) & 2,001 & 469 & 1,184 & 1,972 & 3,152 \\
\hline State Income Taxes (pc) & 323 & 219 & 0 & 367 & 856 \\
\hline
\end{tabular}

Notes: All dollar terms are expressed in 2005 dollars; the government finance terms were deflated using the state and local GDP deflator, while the county income was deflated using the GDP deflator.

Table 4: First Stage Regressions I

\begin{tabular}{|c|c|c|c|c|c|}
\hline & (1) & (2) & (3) & (4) & (5) \\
\hline & & Total IGR & & Federal IGR & State IGR \\
\hline \multirow[t]{2}{*}{$\overline{\text { GRS }}$} & $1.50 * * *$ & $1.36 * * *$ & $1.59 * * *$ & $1.12 * * *$ & 0.39 \\
\hline & $(0.24)$ & $(0.24)$ & $(0.16)$ & $(0.08)$ & $(0.25)$ \\
\hline Cubic baseline controls & $\mathrm{X}$ & & $\mathrm{X}$ & $\mathrm{X}$ & $\mathrm{X}$ \\
\hline Linear baseline controls & & $\mathrm{X}$ & & & \\
\hline Population Weighted & $\mathrm{X}$ & $\mathrm{X}$ & & $\mathrm{X}$ & $\mathrm{X}$ \\
\hline Observations & 14,378 & 14,378 & 14,378 & 14,378 & 14,378 \\
\hline Adjusted R2 & 0.346 & 0.313 & 0.197 & 0.377 & 0.387 \\
\hline Partial R2 & 0.021 & 0.018 & 0.016 & 0.037 & 0.002 \\
\hline F-Stat & 38.3 & 31.9 & 94.9 & 185.3 & 2.4 \\
\hline
\end{tabular}

Notes: Each column represents the results from an OLS regression in which the dependent variable is regressed against the per capita general revenue sharing receipts (GRS), the baseline controls, city and year fixed effects, interactions between the year and the city fiscal year timing, and state-time trends. The dependent variable is total per capita intergovernmental revenues (IGR) in Columns (1)-(3), federal intergovernmental revenues in Column (4), and state intergovernmental revenues in Column (5). The baseline controls are city population, lagged per capita tax revenue, lagged "tax effort", lagged per capita county income, lagged state-level total taxes, lagged state per capita income, and lagged state government individual income taxes. In Column (2), the baseline controls are entered linearly; otherwise, they are entered as cubic polynomials. The population-weighting is shown in the table. All ASG finance variable are deflated using the state and local GDP deflator, and all non-ASG variables are adjusted for the city fiscal years as discussed in the text. Standard errors are clustered at the city level.

${ }^{*} \mathrm{p}<0.10,{ }^{* *} \mathrm{p}<0.5,{ }^{* * *} \mathrm{p}<0.01$ 
Table 5: First Stage Regressions II

\begin{tabular}{lcc}
\hline \hline & $(1)$ & $(2)$ \\
& Total IGR & IGR*Bargain \\
\hline GRS & $1.48^{* * *}$ & 0.06 \\
& $(0.22)$ & $(0.19)$ \\
GRS*Bargain & 0.01 & $1.47 * *$ \\
& $(0.39)$ & $(0.35)$ \\
\hline Union Interactions & $\mathrm{X}$ & $\mathrm{X}$ \\
Observations & 14,378 & 14,378 \\
Adjusted R2 & 0.354 & 0.439 \\
Partial R2 & 0.020 & 0.023 \\
F-Stat & 45.7 & 16.6 \\
\hline \hline
\end{tabular}

Notes: Each column represents an OLS regression in which the dependent variable is regressed against the per capita general revenue sharing receipts (GRS), the interaction of GRS with the bargaining indicator variable (GRS*Bargaining), the baseline controls, the baseline controls interacted with the bargaining indicator, city and year fixed effects, interactions between the year and the city fiscal year timing, and state-time trends. The dependent variable is total per capita intergovernmental transfers (IGR) in Column (1), and IGR interacted with the bargaining indicator variable in Column (2). The baseline controls are cubic polynomials of city population, lagged per capita tax revenue, lagged "tax effort", lagged per capita county income, lagged statelevel total taxes, lagged state per capita income, and lagged state government individual income taxes. All regressions are population-weighted. All ASG finance variable are deflated using the state and local GDP deflator, and all non-ASG variables are adjusted for the city fiscal years as discussed in the text. Standard errors are clustered at the city level.

${ }^{*} \mathrm{p}<0.10,{ }^{* *} \mathrm{p}<0.5, * * * \mathrm{p}<0.01$

Table 6: Total Expenditures Regressions

\begin{tabular}{|c|c|c|c|c|c|}
\hline & (1) & (2) & (3) & (4) & (5) \\
\hline & \multicolumn{5}{|c|}{ OLS Results } \\
\hline Total IGR & $\begin{array}{c}0.66^{* * *} \\
(0.17)\end{array}$ & $\begin{array}{c}0.66^{* * *} \\
(0.18)\end{array}$ & $\begin{array}{c}0.97 * * * \\
(0.11)\end{array}$ & $\begin{array}{c}0.94^{* * *} \\
(0.09)\end{array}$ & $\begin{array}{c}1.01^{* * *} \\
(0.07)\end{array}$ \\
\hline \multirow[t]{2}{*}{ Total IGR*Bargain } & & & $\begin{array}{c}-0.35^{* * *} \\
(0.12) \\
\end{array}$ & $\begin{array}{c}-0.31 * * \\
(0.14) \\
\end{array}$ & $\begin{array}{c}-0.40^{* *} \\
(0.17) \\
\end{array}$ \\
\hline & \multicolumn{5}{|c|}{ IV Results } \\
\hline Total IGR (per capita) & $\begin{array}{c}0.83^{* * *} \\
(0.16)\end{array}$ & $\begin{array}{c}0.89 * * * \\
(0.16)\end{array}$ & $\begin{array}{c}1.03^{* * *} \\
(0.23)\end{array}$ & $\begin{array}{c}0.92 * * * \\
(0.22)\end{array}$ & $\begin{array}{c}0.96^{* * * *} \\
(0.21)\end{array}$ \\
\hline Total IGR*Bargain & & & $\begin{array}{l}-0.22 \\
(0.19) \\
\end{array}$ & $\begin{array}{l}-0.03 \\
(0.18) \\
\end{array}$ & $\begin{array}{l}-0.08 \\
(0.27)\end{array}$ \\
\hline Government FE & $\mathrm{X}$ & $\mathrm{X}$ & $\mathrm{X}$ & $\mathrm{X}$ & $\mathrm{X}$ \\
\hline Year Fixed Effects & $\mathrm{X}$ & $\mathrm{X}$ & $\mathrm{X}$ & $\mathrm{X}$ & $\mathrm{X}$ \\
\hline State*Time Trend & & $\mathrm{X}$ & & $\mathrm{X}$ & $\mathrm{X}$ \\
\hline Fiscal Year Dummies & $\mathrm{X}$ & $\mathrm{X}$ & $\mathrm{X}$ & $\mathrm{X}$ & $\mathrm{X}$ \\
\hline Union Interactions & & & & & $\mathrm{X}$ \\
\hline Population Weighted & $\mathrm{X}$ & $\mathrm{X}$ & $\mathrm{X}$ & $\mathrm{X}$ & $\mathrm{X}$ \\
\hline Observations & 14,378 & 14,378 & 14,378 & 14,378 & 14,378 \\
\hline
\end{tabular}

Notes: The dependent variable in all regressions is total per capita city expenditures. The top panel shows OLS regressions and the bottom panel shows 2SLS IV regressions. In Columns (1) and (2) of the bottom panel, total per capita intergovernmental revenues (IGR) are instrumented by per capita general revenue sharing receipts (GRS). In Columns (3)-(5), IGR and IGR interacted with the bargaining indicator (IGR*Bargaining) are instrumented by GRS and GRS interacted with the bargaining indicator. The additional regressors in each column include the baseline controls, city and year fixed effects, and interactions between the year and the city fiscal year timing. Columns (2), (4), and (5) also include state-time trends, and Column (5) includes the baseline controls interacted with the bargaining indicator. The baseline controls are cubic polynomials of each of: city population, lagged per capita tax revenue, lagged "tax effort", lagged per capita county income, lagged state-level total taxes, lagged state per capita income, and lagged state government individual income taxes. All regressions are population-weighted. All ASG finance variable are deflated using the state and local GDP deflator, and all non-ASG variables are adjusted for the city fiscal years as discussed in the text. Standard errors are clustered at the city level.

${ }^{*} \mathrm{p}<0.10,{ }^{* *} \mathrm{p}<0.5,{ }^{* * *} \mathrm{p}<0.01$ 
Table 7: Finance Components

\begin{tabular}{lcccc}
\hline \hline & $(1)$ & $(2)$ & $(3)$ & $(4)$ \\
& TotalExp & RevOwnSource & DebtIssue & DCashSec \\
\hline Total IGR & $0.96^{* * *}$ & 0.20 & -0.35 & -0.02 \\
& $(0.21)$ & $(0.14)$ & $(0.27)$ & $(0.31)$ \\
Total IGR*Bargain & -0.08 & -0.10 & 0.32 & $(0.42)$ \\
& $(0.27)$ & $(0.13)$ & 14,378 & $(0.32)$ \\
\hline Observations & 14,378 & 14,378 & 14,378 \\
\hline \hline
\end{tabular}

Notes: Each column represents the results from a 2SLS IV regression in which total per capita intergovernmental revenues (IGR) and IGR interacted with the bargaining indicator (IGR*Bargaining) are instrumented by per capita general revenue sharing receipts (GRS) and GRS interacted with the bargaining indicator. The dependent variables in Columns (1)-(4) are, respectively, per capita total expenditures, per capita own source revenue, per capita net debt issued, and the per capita annual change in the city's cash and security holdings. In addition to IGR and IGR*Bargaining, the regressors in each column include the baseline controls, the baseline controls interacted with the bargaining indicator, city and year fixed effects, interactions between the year and the city fiscal year timing, and state-time trends. The baseline controls are cubic polynomials of city population, lagged per capita tax revenue, lagged "tax effort", lagged per capita county income, lagged state-level total taxes, lagged state per capita income, and lagged state government individual income taxes. All regressions are population-weighted. All ASG finance variable are deflated using the state and local GDP deflator, and all non-ASG variables are adjusted for the city fiscal years as discussed in the text. Standard errors are clustered at the city level.

${ }^{*} \mathrm{p}<0.10,{ }^{* *} \mathrm{p}<0.5, * * * \mathrm{p}<0.01$

Table 8: Expenditure Components

\begin{tabular}{lccccc}
\hline \hline & $(1)$ & $(2)$ & $(3)$ & $(4)$ & $(5)$ \\
& Wage Norm & Emp Norm & CapOutlays & RetExp & DRetCashSec \\
\hline Total IGR & 0.21 & $0.41^{* * *}$ & $0.26^{*}$ & -0.03 & 0.00 \\
& $(0.13)$ & $(0.11)$ & $(0.16)$ & $(0.02)$ & $(0.14)$ \\
Total IGR*Bargain & $0.56^{* * *}$ & $-0.29^{* *}$ & -0.26 & 0.03 & -0.17 \\
& $(0.20)$ & $(0.14)$ & $(0.20)$ & $(0.02)$ & $(0.20)$ \\
\hline Observations & 14,378 & 14,378 & 14,378 & 14,378 & 14,378 \\
\hline \hline
\end{tabular}

Notes: The dependent variables in Columns (1)-(5) are, respectively, the normalized wage of government employees, the normalized government employment, per capita capital outlays, per capita retirement expenditures, and the per capita annual change in the city's retirement cash and security holdings. For more details on the specifications, see notes to Table 7.

${ }^{*} \mathrm{p}<0.10,{ }^{* *} \mathrm{p}<0.5,{ }^{* * *} \mathrm{p}<0.01$

Table 9: Recession Effects

\begin{tabular}{lcccc}
\hline \hline & $(1)$ & $(2)$ & $(3)$ & $(4)$ \\
& Total Expenditures & Emp_Norm & Wage_Norm & Capital Outlays \\
\hline Total IGR*(UR-UR_AVE $\geq 2)$ & $0.77^{* *}$ & $0.55^{* * *}$ & 0.17 & -0.08 \\
& $(0.30)$ & $(0.15)$ & $(0.21)$ & $(0.37)$ \\
Total IGR*(UR-UR_AVE <2) & $0.96^{* * *}$ & $0.41^{* * *}$ & 0.17 & 0.23 \\
& $(0.22)$ & $(0.11)$ & $(0.15)$ & $(0.15)$ \\
Total IGR*Bargain*(UR-UR_AVE $\geq 2)$ & 0.16 & $-0.43^{* *}$ & $0.65^{* *}$ & 0.11 \\
Total IGR*Bargain*(UR-UR_AVE < 2) & $(0.35)$ & $(0.18)$ & $(0.31)$ & $(0.40)$ \\
& -0.06 & -0.21 & $0.77^{* * *}$ & -0.17 \\
\hline Observations & $(0.30)$ & $(0.14)$ & $(0.28)$ & $(0.25)$ \\
\hline \hline
\end{tabular}

Notes: Each column represents the results from a 2SLS IV regression in which there are four endogenous variables of interactions with total per capita intergovernmental transfers (IGR) as shown in the table, and four corresponding instruments of the equivalent interactions with per capita general revenue sharing receipts (GRS). "UR" refers to the state unemployment rate of the city, and "UR_AVE" refers to the average of the state unemployment rate from 1972 to 1989. All "recession indicators" interacted with IGR are also includes as controls. The dependent variables in Columns (1)-(4) are, respectively, per capita expenditures, normalized employment, normalized wage, and per capita outlays. For more details on the specifications, see notes to Table 7.

${ }^{*} \mathrm{p}<0.10,{ }^{* *} \mathrm{p}<0.5,{ }^{* * *} \mathrm{p}<0.01$ 
Table 10: Robustness I

\begin{tabular}{|c|c|c|c|c|c|}
\hline & (1) & (2) & (3) & (4) & (5) \\
\hline & \multicolumn{5}{|c|}{ Total Expenditures } \\
\hline Total IGR & $\begin{array}{c}0.96 * * * \\
(0.21)\end{array}$ & $\begin{array}{c}1.03^{* * *} \\
(0.19)\end{array}$ & $\begin{array}{c}0.92 * * * \\
(0.21)\end{array}$ & $\begin{array}{c}0.87 * * * \\
(0.22)\end{array}$ & $\begin{array}{c}0.81^{* * *} \\
(0.20)\end{array}$ \\
\hline \multirow[t]{2}{*}{ Total IGR*Bargain } & $\begin{array}{c}-0.08 \\
(0.27) \\
\end{array}$ & $\begin{array}{c}0.02 \\
(0.27) \\
\end{array}$ & $\begin{array}{c}0.10 \\
(0.26) \\
\end{array}$ & $\begin{array}{c}0.03 \\
(0.25) \\
\end{array}$ & $\begin{array}{c}0.04 \\
(0.20) \\
\end{array}$ \\
\hline & \multicolumn{5}{|c|}{ Normalized Wages } \\
\hline Total IGR & $\begin{array}{c}0.21 \\
(0.13)\end{array}$ & $\begin{array}{l}0.37 * \\
(0.20)\end{array}$ & $\begin{array}{c}0.36 * * \\
(0.16)\end{array}$ & $\begin{array}{c}0.17 \\
(0.10)\end{array}$ & $\begin{array}{l}0.18 \\
(0.15)\end{array}$ \\
\hline \multirow[t]{2}{*}{ Total IGR*Bargain } & $\begin{array}{c}0.56^{* * *} \\
(0.20) \\
\end{array}$ & $\begin{array}{c}0.40 \\
(0.25) \\
\end{array}$ & $\begin{array}{l}0.38 * \\
(0.23) \\
\end{array}$ & $\begin{array}{c}0.14 \\
(0.15) \\
\end{array}$ & $\begin{array}{c}0.08 \\
(0.14) \\
\end{array}$ \\
\hline & \multicolumn{5}{|c|}{ Normalized Employment } \\
\hline Total IGR & $\begin{array}{c}0.41 * * * \\
(0.11)\end{array}$ & $\begin{array}{c}0.47 * * * \\
(0.18)\end{array}$ & $\begin{array}{c}0.33^{* * *} \\
(0.10)\end{array}$ & $\begin{array}{c}0.42 * * * \\
(0.12)\end{array}$ & $\begin{array}{c}0.16 \\
(0.17)\end{array}$ \\
\hline Total IGR*Bargain & $\begin{array}{c}-0.29 * * \\
(0.14) \\
\end{array}$ & $\begin{array}{c}-0.37 * * \\
(0.14) \\
\end{array}$ & $\begin{array}{l}-0.15 \\
(0.14) \\
\end{array}$ & $\begin{array}{l}-0.00 \\
(0.18) \\
\end{array}$ & $\begin{array}{c}0.03 \\
(0.17) \\
\end{array}$ \\
\hline Population Weighted & $\mathrm{X}$ & $\mathrm{X}$ & $\mathrm{X}$ & $\mathrm{X}$ & \\
\hline $\begin{array}{l}\text { Pop Cutoff } \\
\text { Bargain Measure } \\
\text { Observations }\end{array}$ & $\begin{array}{c}\text { Standard } \\
14,378\end{array}$ & $\begin{array}{c}\text { Union Dues } \\
14,378\end{array}$ & $\begin{array}{c}\text { Scope: Wages } \\
14,360\end{array}$ & $\begin{array}{c}\text { No Top } 5 \\
\text { Standard } \\
14,288\end{array}$ & $\begin{array}{c}\text { Standard } \\
14,378\end{array}$ \\
\hline
\end{tabular}

Notes: Each column represents the results from a 2SLS IV regression in which total per capita intergovernmental revenues (IGR) and IGR interacted with the bargaining indicator (IGR*Bargaining) are instrumented by per capita general revenue sharing receipts (GRS) and GRS interacted with the bargaining indicator. The dependent variables in the top, middle, and bottom panels are, respectively, per capita expenditures, normalized wages, and normalized employment. Alternative bargaining measures are used in Columns (2) and (3) as described in the text. In Column (4), the top 5 largest cities are dropped, and in Column (5), the regression is not population-weighted. For more details on the specifications, see notes to Table 7 .

${ }^{*} \mathrm{p}<0.10,{ }^{* *} \mathrm{p}<0.5,{ }^{* * *} \mathrm{p}<0.01$ 
Table 11: Robustness II

\begin{tabular}{|c|c|c|c|c|c|}
\hline & (1) & (2) & (3) & (4) & (5) \\
\hline & \multicolumn{5}{|c|}{ Total Expenditures } \\
\hline Total IGR & $\begin{array}{c}0.96^{* * *} \\
(0.21)\end{array}$ & $\begin{array}{c}0.96^{* * *} \\
(0.21)\end{array}$ & $\begin{array}{c}0.90^{* * *} \\
(0.29)\end{array}$ & $\begin{array}{c}0.98^{* * *} \\
(0.21)\end{array}$ & $\begin{array}{c}1.02 * * * \\
(0.20)\end{array}$ \\
\hline \multirow[t]{2}{*}{ Total IGR*Bargain } & $\begin{array}{l}-0.08 \\
(0.27)\end{array}$ & $\begin{array}{l}-0.07 \\
(0.27)\end{array}$ & $\begin{array}{l}-0.07 \\
(0.27)\end{array}$ & $\begin{array}{l}-0.17 \\
(0.26)\end{array}$ & $\begin{array}{l}-0.13 \\
(0.28)\end{array}$ \\
\hline & \multicolumn{5}{|c|}{ Normalized Wages } \\
\hline Total IGR & $\begin{array}{c}0.21 \\
(0.13)\end{array}$ & $\begin{array}{c}0.22 \\
(0.13)\end{array}$ & $\begin{array}{c}0.21 \\
(0.22)\end{array}$ & $\begin{array}{l}0.22 * \\
(0.13)\end{array}$ & $\begin{array}{c}0.22 \\
(0.14)\end{array}$ \\
\hline \multirow[t]{2}{*}{ Total IGR*Bargain } & $\begin{array}{c}0.56 * * * \\
(0.20)\end{array}$ & $\begin{array}{c}0.55 * * * \\
(0.20)\end{array}$ & $\begin{array}{c}0.55 * * * \\
(0.21)\end{array}$ & $\begin{array}{c}0.56 * * * \\
(0.21)\end{array}$ & $\begin{array}{c}0.56 * * \\
(0.22) \\
\end{array}$ \\
\hline & \multicolumn{5}{|c|}{ Normalized Employment } \\
\hline Total IGR & $\begin{array}{c}0.41^{* * *} \\
(0.11)\end{array}$ & $\begin{array}{c}0.41^{* * *} \\
(0.11)\end{array}$ & $\begin{array}{c}0.31^{* *} \\
(0.15)\end{array}$ & $\begin{array}{c}0.41^{* * *} \\
(0.11)\end{array}$ & $\begin{array}{c}0.42 * * * \\
(0.11)\end{array}$ \\
\hline Total IGR*Bargain & $\begin{array}{c}-0.29 * * \\
(0.14)\end{array}$ & $\begin{array}{c}-0.29 * * \\
(0.14)\end{array}$ & $\begin{array}{c}-0.29 * * \\
(0.13)\end{array}$ & $\begin{array}{c}-0.32 * * \\
(0.14)\end{array}$ & $\begin{array}{c}-0.27^{*} \\
(0.14) \\
\end{array}$ \\
\hline Baseline Controls & $\mathrm{X}$ & $\mathrm{X}$ & $\mathrm{X}$ & $\mathrm{X}$ & $\mathrm{X}$ \\
\hline Party of Governor & & $\mathrm{X}$ & $\mathrm{X}$ & & \\
\hline Party of Governor*GRS & & & $\mathrm{X}$ & & \\
\hline City 3-Factor Formula & & & & $\mathrm{X}$ & $\mathrm{X}$ \\
\hline State 3-Factor Formula & & & & & $\mathrm{X}$ \\
\hline Observations & 14,378 & 14,378 & 14,378 & 14,378 & 14,378 \\
\hline
\end{tabular}

Notes: Each column represents the results from a 2SLS IV regression in which total per capita intergovernmental revenues (IGR) and IGR interacted with the bargaining indicator (IGR*Bargaining) are instrumented by per capita general revenue sharing receipts (GRS) and GRS interacted with the bargaining indicator. The dependent variables in the top, middle, and bottom panels are, respectively, per capita expenditures, normalized wages, and normalized employment. Column (2) includes as a control an indicator for whether the city was residing in a state with a democratic governor. Data were received from Professor Jim Snyder. Column (2) includes the interaction of this indicator with GRS. Column (4) includes the product of city-level population, tax effort, and inverse per capita income. Column (5) includes, in addition, the product of state-level population, tax effort, and inverse per capita income. For more details on the specifications, see notes to Table 7.

${ }^{*} \mathrm{p}<0.10,{ }^{* *} \mathrm{p}<0.5,{ }^{* * *} \mathrm{p}<0.01$ 
Table 12: Macroeconomics Crosswalk

\begin{tabular}{|c|c|c|c|c|c|}
\hline & (1) & $(2)$ & (3) & (4) & (5) \\
\hline & Emp_Norm & \multicolumn{2}{|c|}{ City Gov't Employees (1000) } & $\begin{array}{l}\text { BEA Gov't } \\
\text { Employees }\end{array}$ & $\begin{array}{l}\text { BEA Private and } \\
\text { Gov't Employees }\end{array}$ \\
\hline Scaled IGR & $\begin{array}{c}0.41 * * * \\
(0.11)\end{array}$ & $\begin{array}{c}10.83^{* * *} \\
(2.87)\end{array}$ & $\begin{array}{c}14.52 * * * \\
(5.28)\end{array}$ & $\begin{array}{l}9.87 * \\
(5.53)\end{array}$ & $\begin{array}{l}31.99^{*} \\
(17.98)\end{array}$ \\
\hline Scaled IGR*Bargain & $\begin{array}{c}-0.29 * * \\
(0.14) \\
\end{array}$ & $\begin{array}{c}-8.27 * * * \\
(3.18) \\
\end{array}$ & $\begin{array}{c}-15.54 * * * \\
(4.66) \\
\end{array}$ & $\begin{array}{c}-12.65^{* *} \\
(5.47) \\
\end{array}$ & $\begin{array}{c}-45.04^{* *} \\
(22.25) \\
\end{array}$ \\
\hline $\begin{array}{l}\text { City-County Population } \\
\text { Ratio Cutoff }\end{array}$ & 0 & 0 & 0.5 & 0.5 & 0.5 \\
\hline Observations & 14,379 & 14,379 & 3,705 & 3,705 & 3,705 \\
\hline
\end{tabular}

Notes: Each column represents the results from a 2SLS IV regression in which total per capita intergovernmental revenues (IGR) and IGR interacted with the bargaining indicator (IGR*Bargaining) are instrumented by per capita general revenue sharing receipts (GRS) and GRS interacted with the bargaining indicator. The dependent variables in Columns (1)-(5) are, respectively, per capita normalized city government employment, city government employment per 1000 in the city population, city government employment per 1000 in the city population, total government employment per 1000 in the county population, and total employment per 1000 in the county population. Columns (3)-(5) limit the sample to cities that make up at least 50 percent of their counties. To scale appropriately in Columns (4) and (5), the per capita city intergovernmental transfers are scaled by the county area to city IGR ratio from the most recent government census year. This scaling is discussed and explained in the text. For more details on the specifications, see notes to Table 7.

${ }^{*} \mathrm{p}<0.10,{ }^{* *} \mathrm{p}<0.5,{ }^{* * *} \mathrm{p}<0.01$

Table 13: Macroeconomic Effects

\begin{tabular}{lccccc}
\hline \hline & $(1)$ & \multicolumn{2}{c}{$\begin{array}{c}(2) \\
\text { Total Employment (1000 per capita) }\end{array}$} \\
\hline Scaled IGR & \multicolumn{7}{c}{$\begin{array}{c}(5) \\
\end{array}$} & $31.99^{*}$ & 14.84 & 5.50 & $52.59^{*}$ & $33.76^{*}$ \\
Scaled IGR*Bargain & $(17.98)$ & $(15.98)$ & $(40.53)$ & $(26.85)$ & $(18.19)$ \\
& $-45.04^{*}$ & $-29.62^{*}$ & -15.79 & $-50.56^{* *}$ & 23.51 \\
& $(22.25)$ & $(17.47)$ & $(25.12)$ & $(19.70)$ & $(30.03)$ \\
\hline State*Time Trend & $\mathrm{X}$ & $\mathrm{X}$ & $\mathrm{X}$ & & $\mathrm{X}$ \\
Union Interactions & $\mathrm{X}$ & $\mathrm{X}$ & $\mathrm{X}$ & $\mathrm{X}$ & $\mathrm{X}$ \\
Population Cutoff & & & & No Top 5 \\
City-County Population & 0.5 & 0.3 & 0.85 & 0.5 & 0.5 \\
Ratio Cutoff & 3,705 & 6,308 & 631 & 3,705 & 3,515 \\
Observations & & & & & \\
\hline \hline
\end{tabular}

Notes: Each column represents the results from a 2SLS IV regression in which total per capita intergovernmental revenues (IGR) and IGR interacted with the bargaining indicator (IGR*Bargaining) are instrumented by per capita general revenue sharing receipts (GRS) and GRS interacted with the bargaining indicator. The dependent variable is total employment per 1000 in the county population. In Columns (1), (4), and (5), the sample is limited to cities that make up at least 50 percent of their counties, in Column (2), the sample is limited to cities that make up at least 30 percent of their counties, and in Column (3), the sample is limited to cities that make up at least 85 percent of their counties. In Column (4), state-time trends are not included, and in Column (5), the top 5 largest cities are dropped. For more details on the specifications, see notes to Table 7.

${ }^{*} \mathrm{p}<0.10,{ }^{* *} \mathrm{p}<0.5, * * * \mathrm{p}<0.01$ 


\section{Figures}

Figure 1: Public and Private Union Coverage

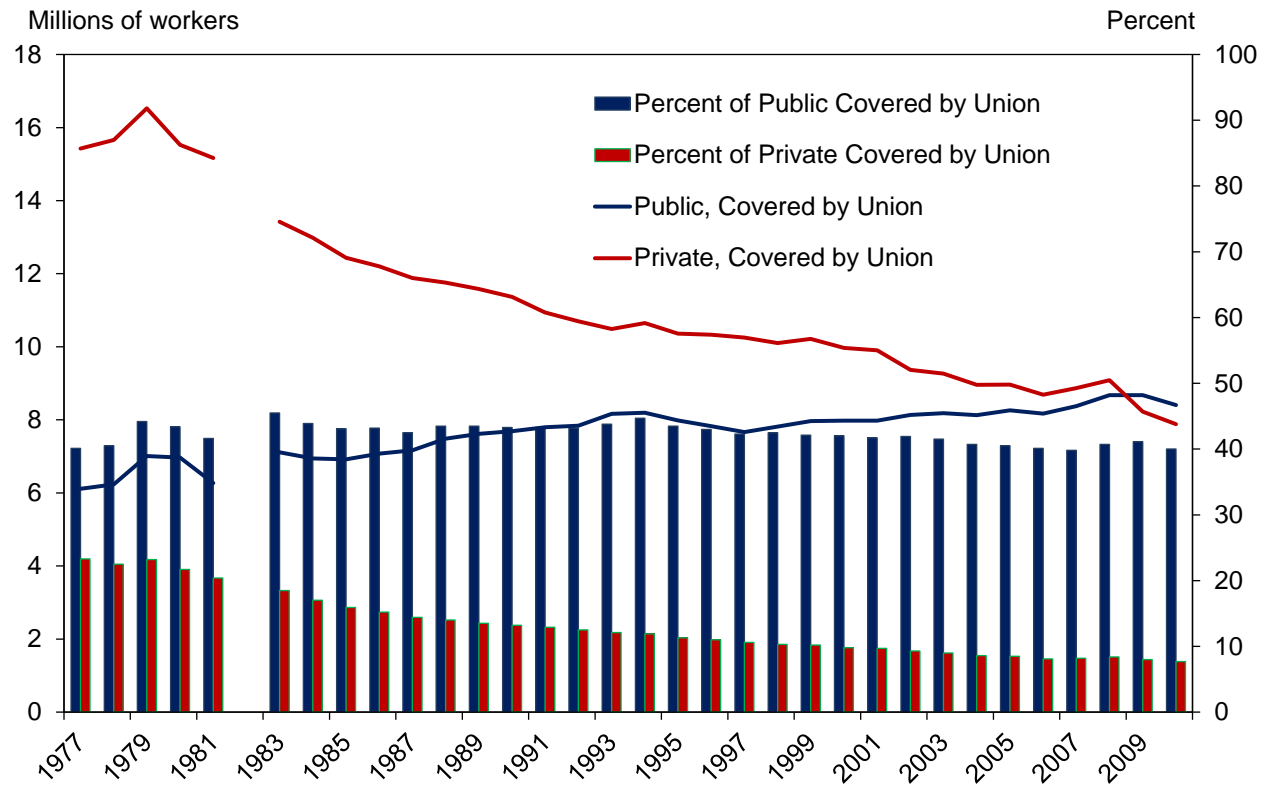

Notes: From Unionstats.com, Hirsch, Macpherson (2011).

Figure 2

Unions

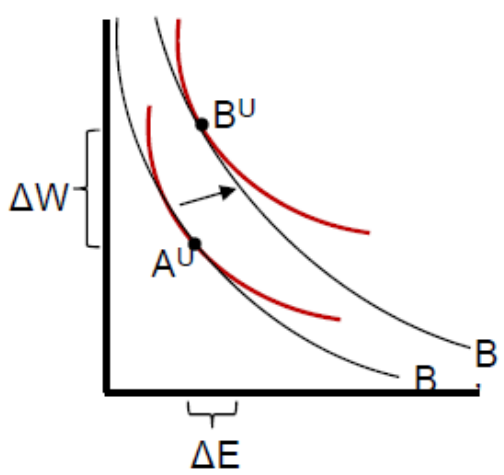

No Unions

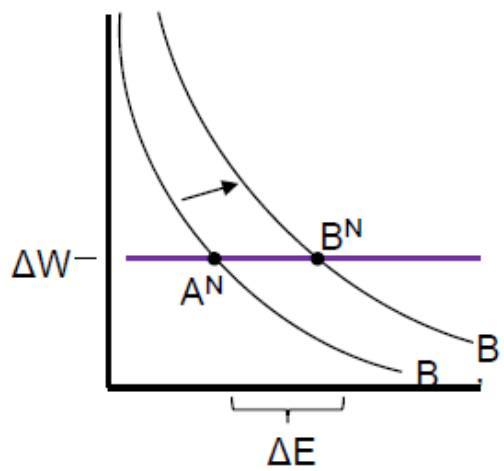


Figure 3: Federal IGR and General Revenue Sharing Funds

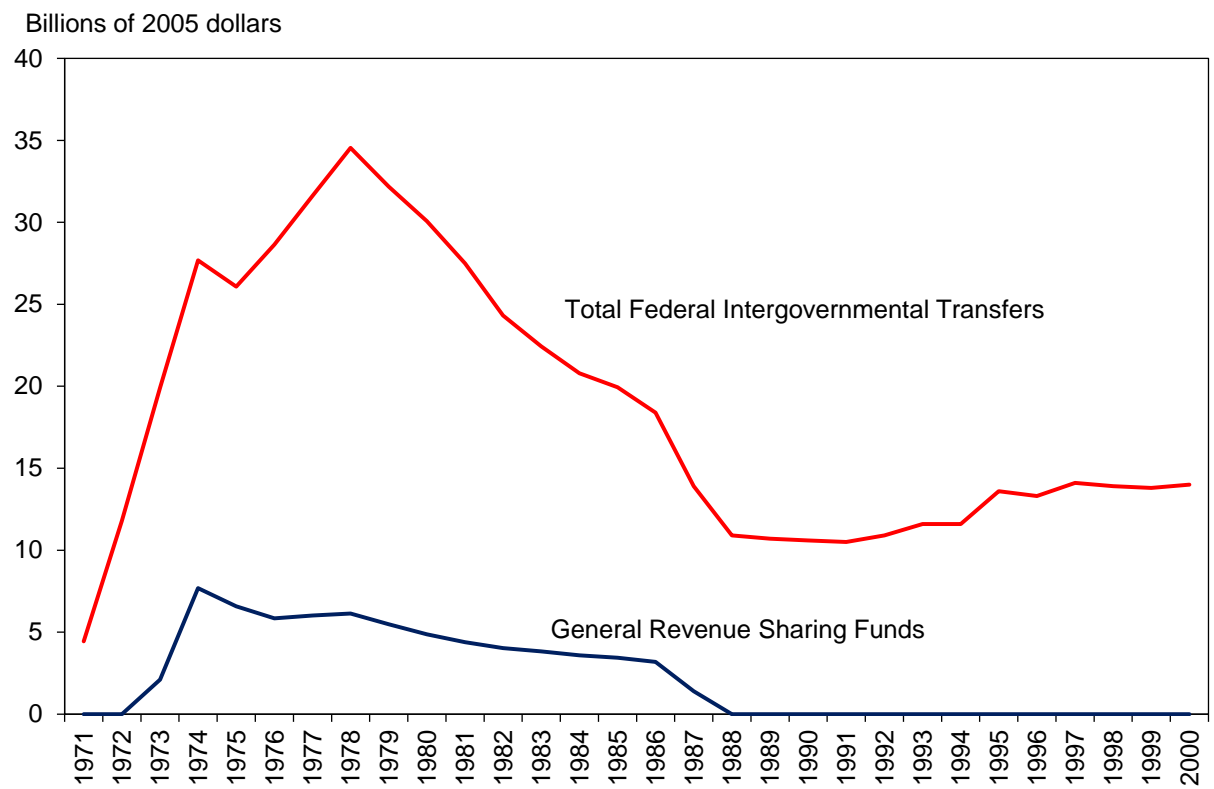

Notes: From the 1971-2000 Annual Surveys of Government Finance.

Figure 4: State Area Allocations

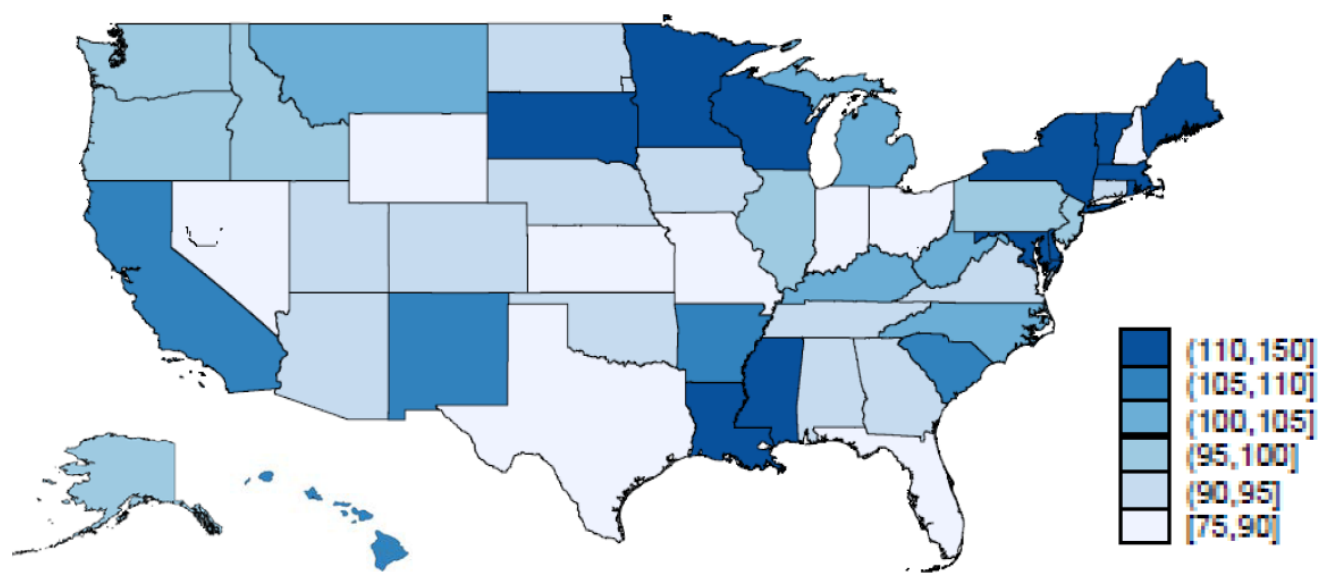

Notes: Data are from the 1977 Annual Survey of Governments. Amounts are per capita amounts in 2005 dollars. 
Figure 5: 1977 General Revenue Sharing Transfers

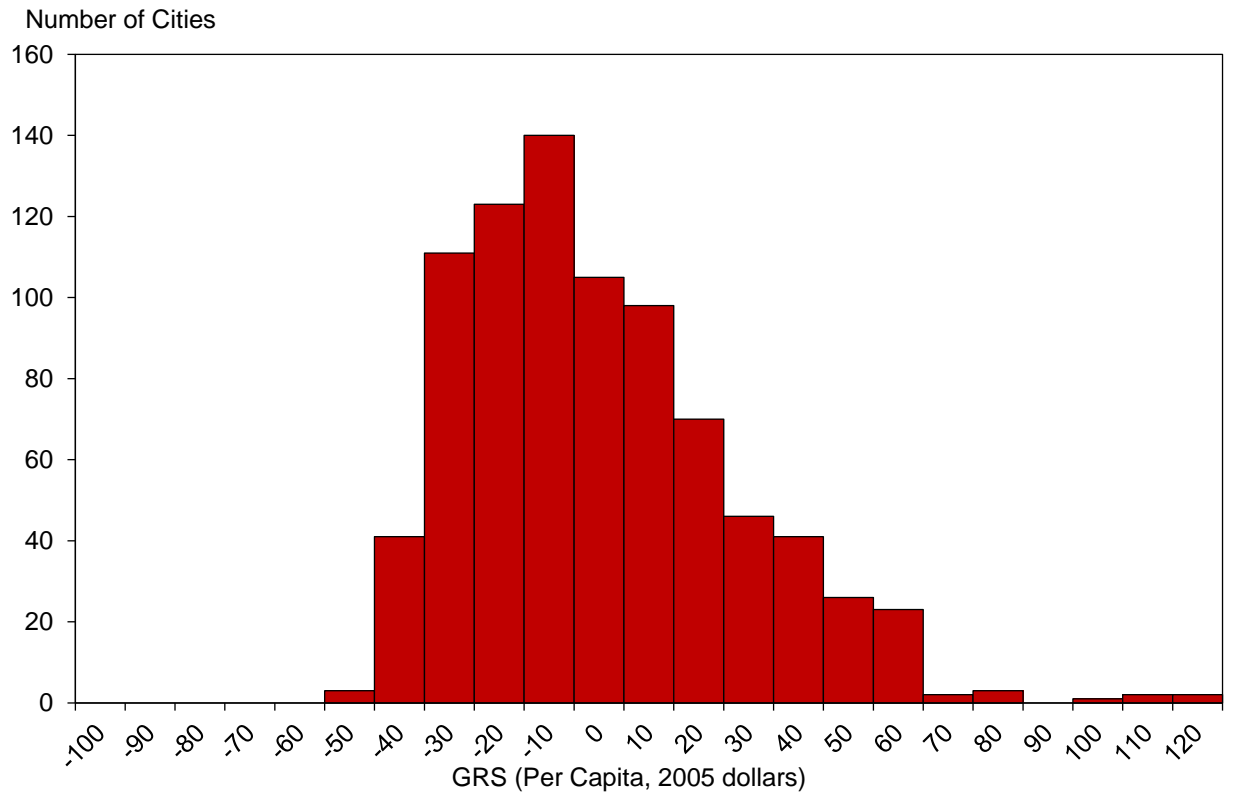

Notes: Data are from the 1977 Census of Governments, and are de-meaned.

Figure 6: 1977 General Revenue Sharing Variation

Number of Cities

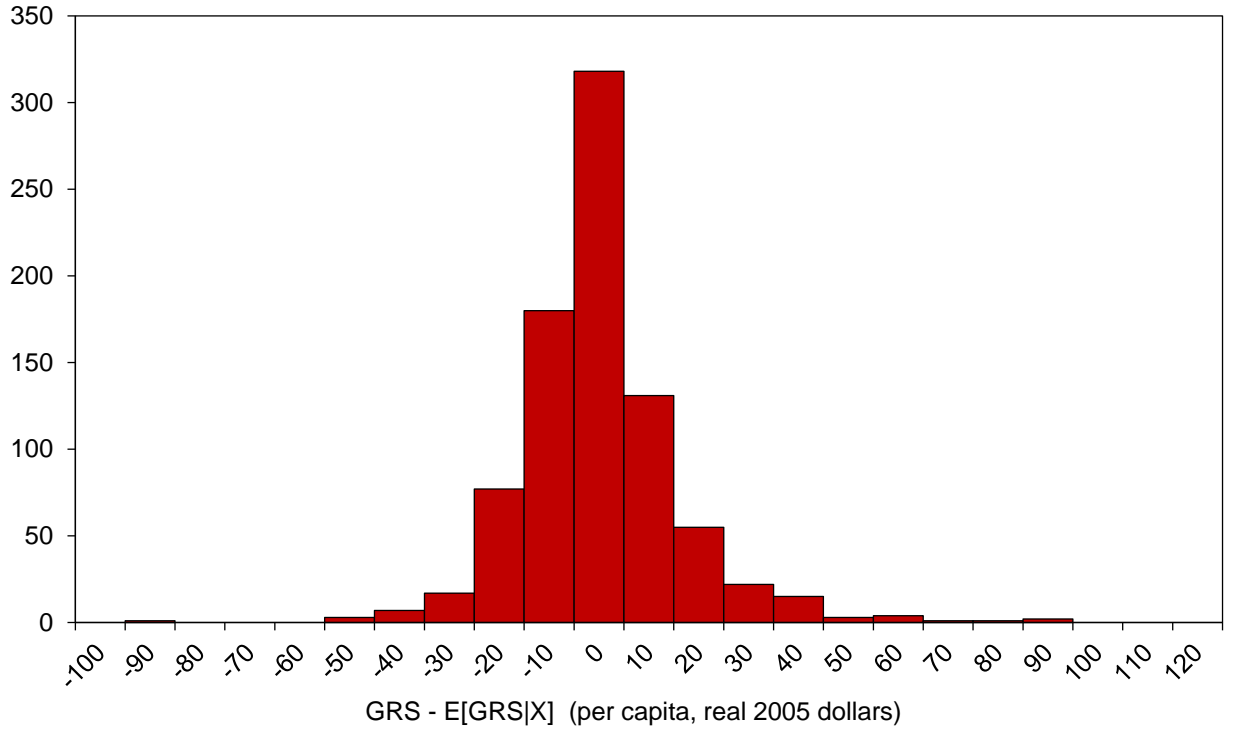

Notes: This histogram shows the residuals produced by the regression of per capita general revenue sharing against cubic polynomials of all of the allocation variables as described in the text. 
Figure 7: Government Consumption and Investment

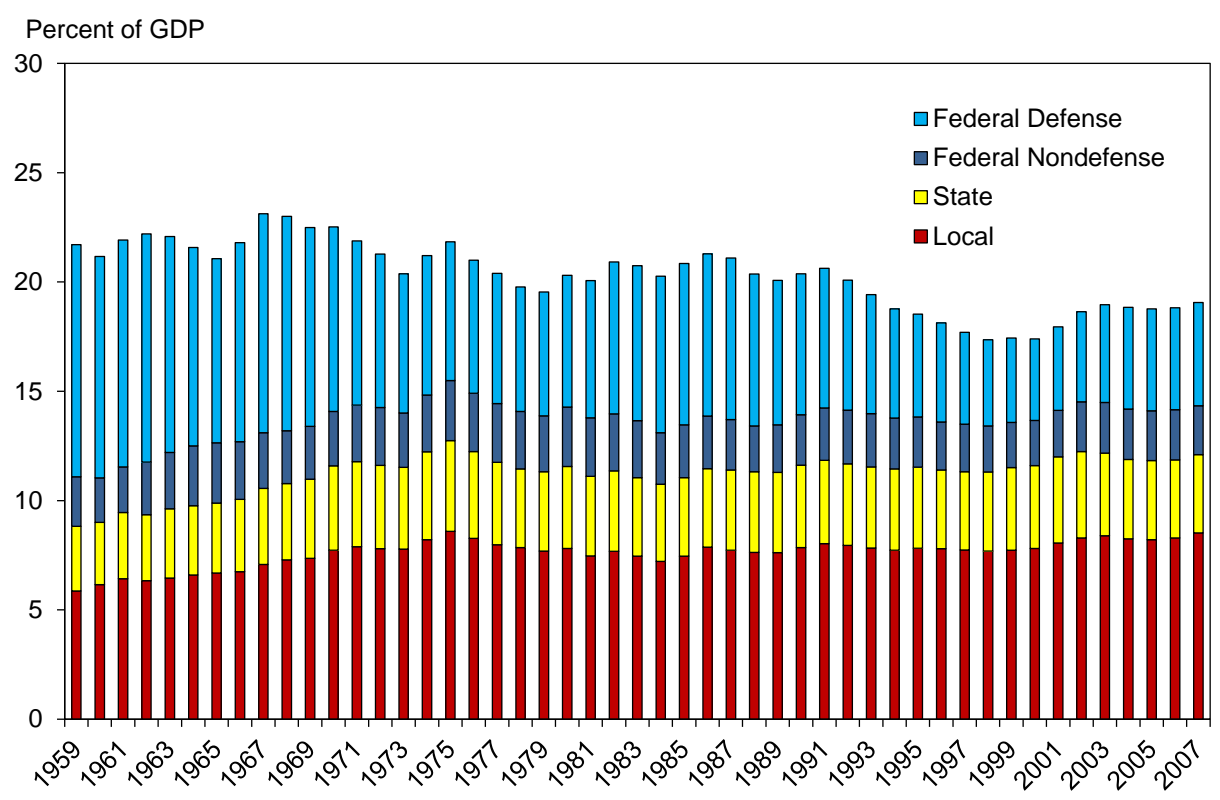

Notes: Bureau of Economic Analysis NIPA Tables 1.15, 3.20, and 3.21.

Figure 8: Timing of Bargaining Law Passage

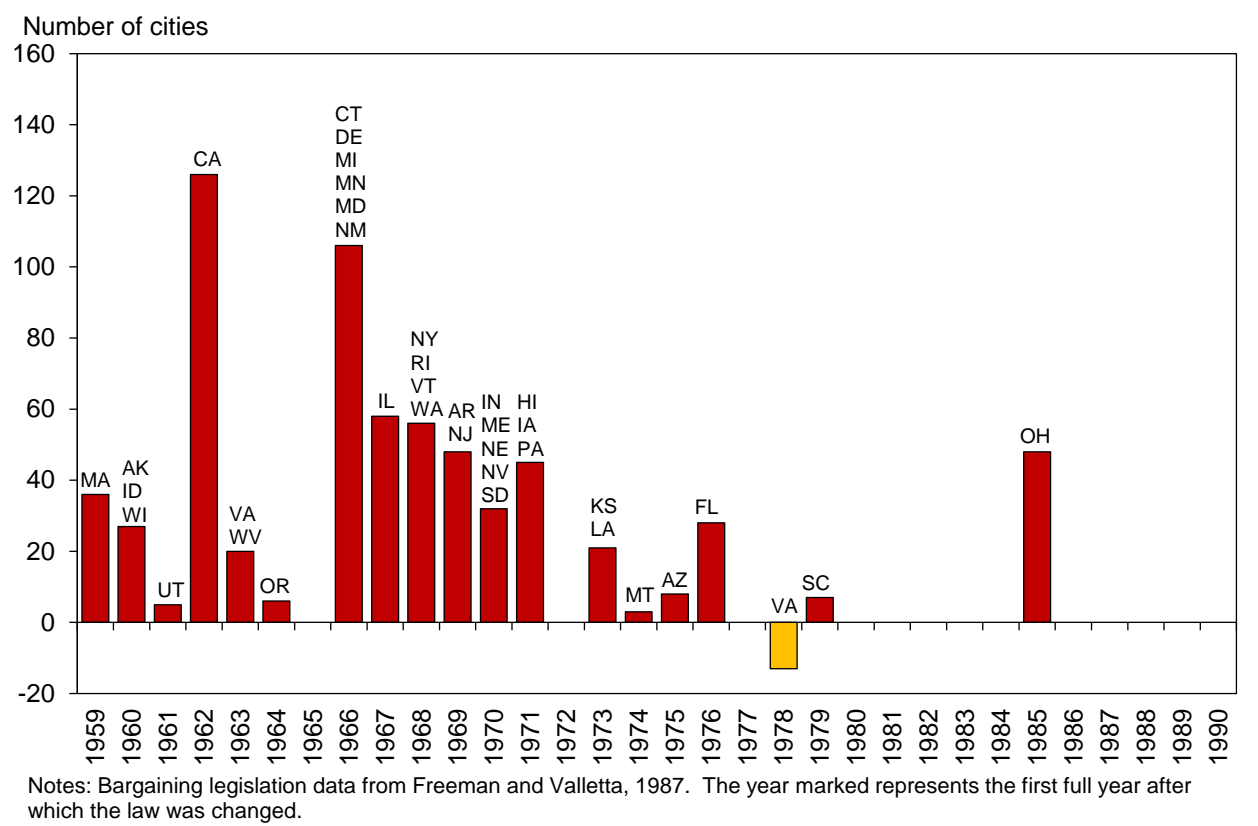


Figure 9: 1972 Bargaining Laws

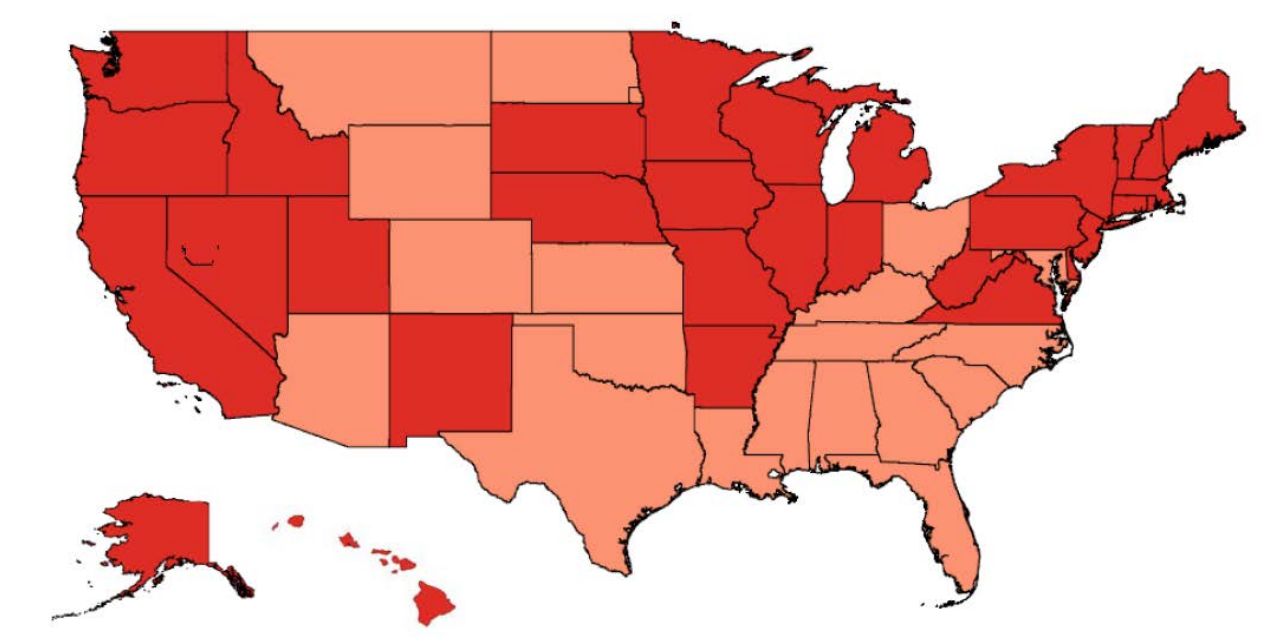

Notes: Dark red represents the existence of a pro-union collective bargaining law in 1977. Light red indicates either the absence of such a law, or the existence of a law specifically prohibiting collective bargaining.

Figure 10: National Unemployment Rate

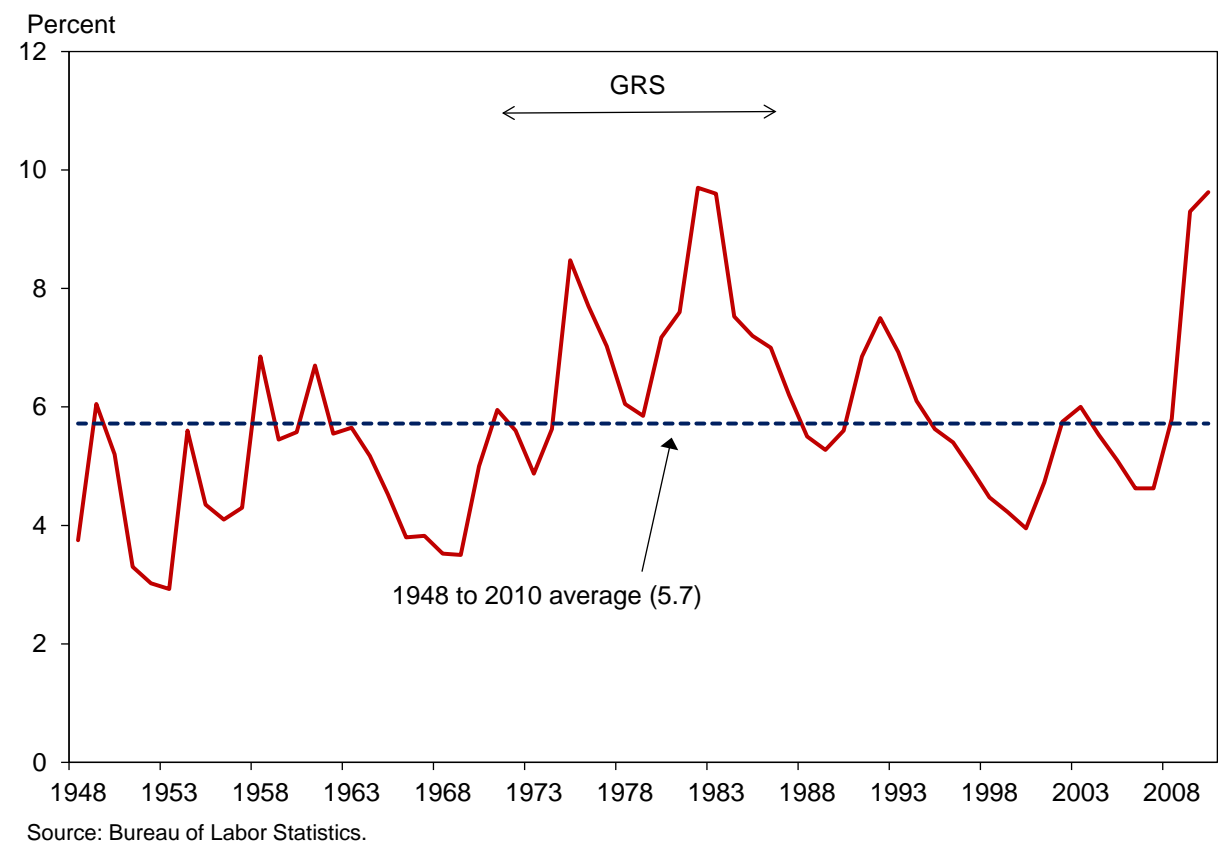


Figure 11: Unemployment Rates

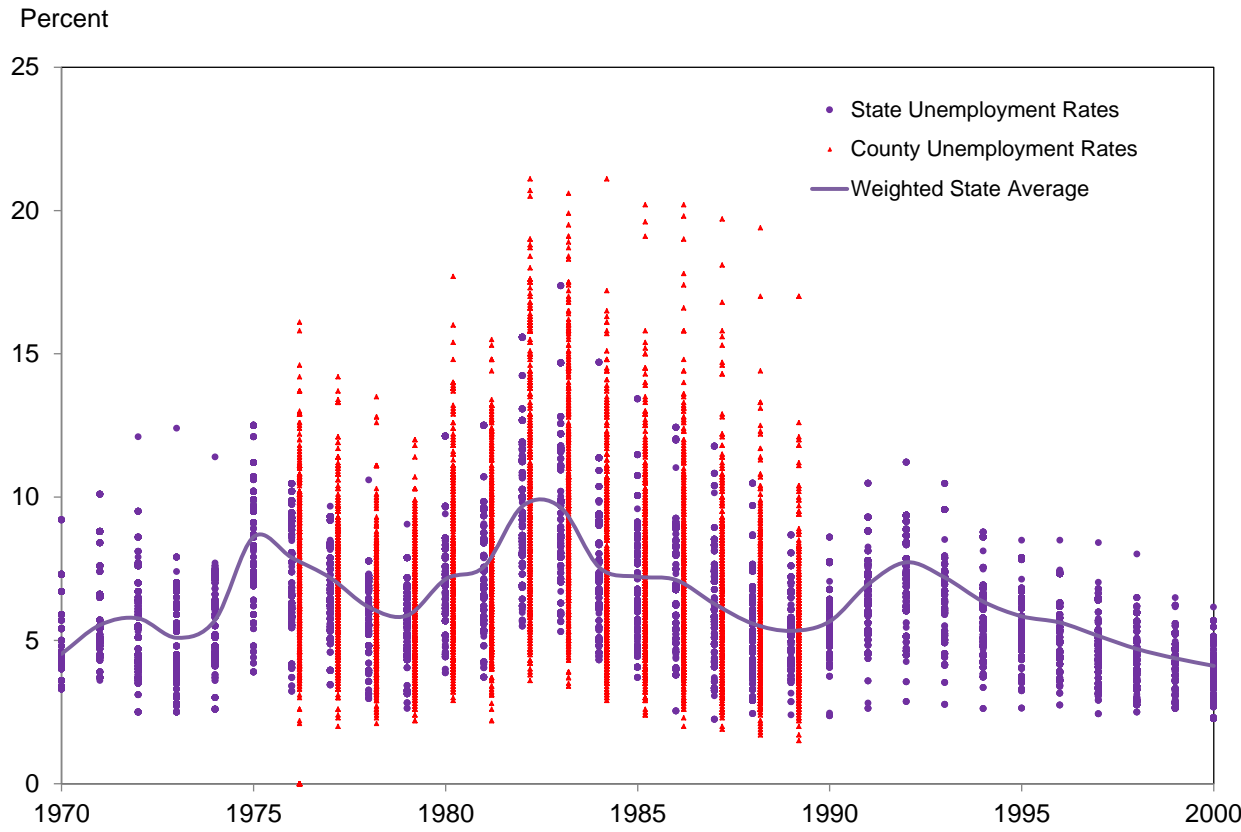

Note: This graph shows a scatterplot of the unemployment rates of the states (1970 to 2000) and the counties (1977 to 1989 ) in which the cities in the sample studied reside. The solid line shows the population-weighted average of the state unemployment rates across all cities in the sample. The state data for 1970 and 1971 are from the BLS and are only available for 27 of the 50 states. The state data from 1972 to 1976 are from Wayne Vroman. Post-1976 county and state data were received upon special request from the BLS.

Figure 12

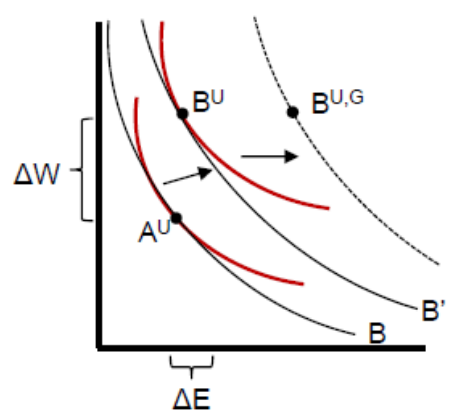

